\title{
BODIE
}

\section{Containment Data Report}

Ted Stubbs

Billy Hudson

Ray Heinle

June 1994

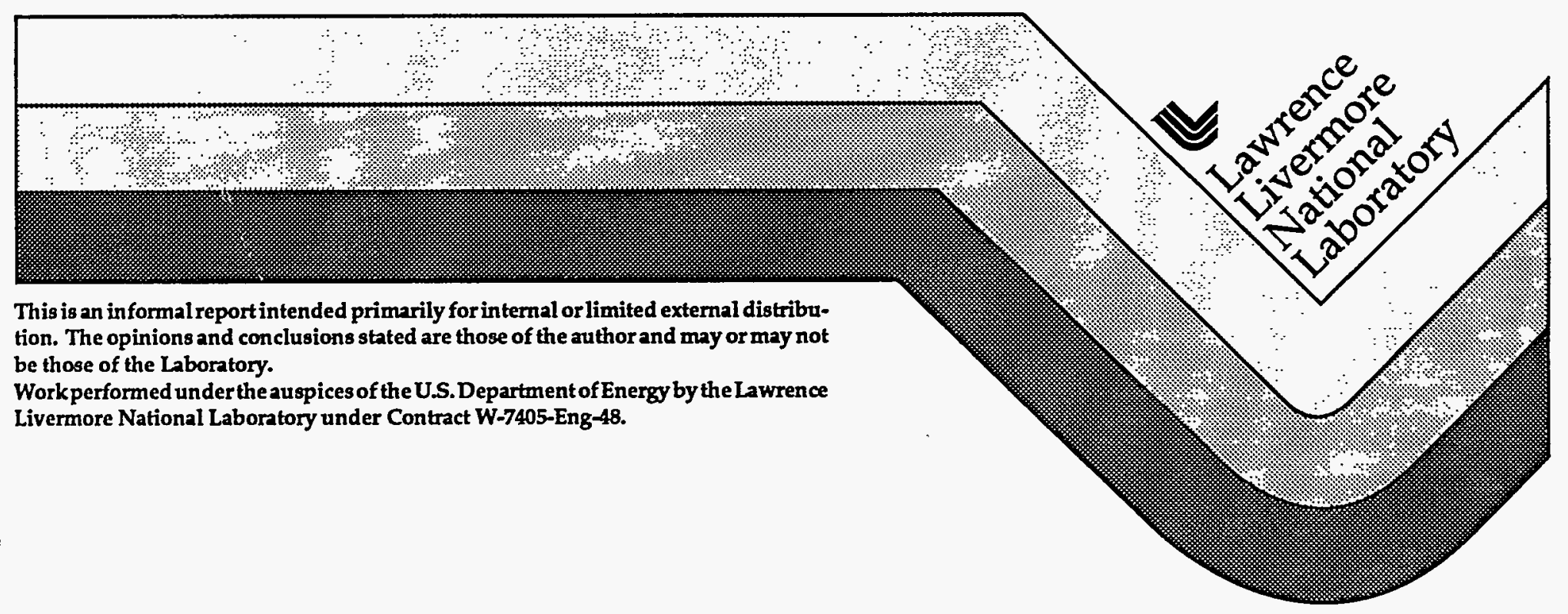


This document was prepared 25 an account of work sponsored by an agency of the United States Government. Neither the United States Government nor the University of California nor any of their employees, makes any warranty, express or implied, or assumes any legal liability or responsibility for the accuracy, completeness, or usefulness of any information, apparatus, product, or process disclosed, or represents that its use would not infringe privately owned rights. Reference herein to any specific commercial products, process, or service by trade name, trademark, manufacturer, or otherwise, does not necessarily constitute or imply its endorsement, recommendation, or favoring by the United States Government or the University of California. The viewsand opinions of authors expressed herein do not necessarily state or reflect those of the United States Government or the University of California, and shall not be used for advertising or product endorsement purposes.

This report has been reproduced directly from the best available copy.

Available to DOE and DOE contractors from the Office of Scientific and Technical Information P.O. Box 62, O2k Ridge, TN 37831

Prices available from (615) 576-8401, FTS 626-8401

Available to the public from the National Technical Information Service

US. Department of Commerce 5285 Port Royal Rd., Springfield, VA 22161 


\section{DISCLAIMER}

Portions of this document may be illegible in electronic image products. Images are produced from the best available original document. 


\begin{tabular}{lll} 
Classification Guide & Topic Number & \multicolumn{1}{c}{ Subject } \\
\cline { 2 - 3 } COK-88-024 & 1.5 .6 & Event announcement \\
NV-89-18 & & Event announcement \\
TCG-WT-1 & 1113 & Contractor identification \\
TCG-WT-1 & 1121 & Personnel identification \\
TCG-WT-1 & 1210 & Geology \\
TVG-WT-1 & 1260 & Crater (map) \\
TCG-WT-1 & 1413 & Statement concerning venting \\
TCG-WT-1 & 1452 & Event announcement \\
TCG-WT-1 & 1831 & Depth of burial \\
TCG-WT-1 & 1843 & Stemming material, amount,etc \\
TCG-WT-1 & 1925 & Diagnostic canister dimensions \\
TCG-WT-1 & 3542.3 & Ground motion \\
TCG-WT-1 & 4810 & Radiation measurement \\
TCG-WT-1 & 4820 & Acceleration, pressure, \\
& & temperature measurement
\end{tabular}


BODIE Instrumentation Summary

\begin{tabular}{|c|c|c|c|}
\hline Instrumentation & $\begin{array}{l}\text { Fielded on } \\
\text { this Event }\end{array}$ & $\begin{array}{c}\text { Data } \\
\text { Retum }\end{array}$ & $\begin{array}{l}\text { Present in } \\
\text { this Report }\end{array}$ \\
\hline $\begin{array}{l}\text { Plua Emplacement } \\
\text { Conductivity } \\
\text { Temperature }\end{array}$ & $\begin{array}{l}\text { yes } \\
\text { yes } \\
\end{array}$ & $\begin{array}{l}\text { yes } \\
\text { yes } \\
\end{array}$ & $\begin{array}{l}\text { yes } \\
\text { yes } \\
\end{array}$ \\
\hline Radiation & yes & yes & yes \\
\hline $\begin{array}{r}\text { Pressure } \\
\text { Stemming } \\
\text { Challenge } \\
\text { Cavity } \\
\text { Atmospheric } \\
\end{array}$ & $\begin{array}{c}\text { yes } \\
\text { no } \\
\text { no } \\
\text { yes } \\
\end{array}$ & $\begin{array}{c}\text { yes } \\
- \\
\text { yes } \\
\end{array}$ & $\begin{array}{c}\text { yes } \\
- \\
- \\
\text { yes }\end{array}$ \\
\hline $\begin{array}{r}\text { Motion } \\
\text { Free Field } \\
\text { Surface } \\
\text { Plug } \\
\text { Stemming } \\
\text { Surface Casing } \\
\text { Emplacement Pipe } \\
\text { Recording Trailer }\end{array}$ & $\begin{array}{l}\text { no } \\
\text { yes } \\
\text { no } \\
\text { yes } \\
\text { no } \\
\text { no } \\
\text { yes }\end{array}$ & $\begin{array}{c}\text { yes } \\
- \\
\text { yes } \\
- \\
- \\
\text { yes }\end{array}$ & $\begin{array}{c}\text { yes } \\
- \\
\text { yes } \\
- \\
- \\
\text { yes }\end{array}$ \\
\hline Hydroyield (a) & yes & yes & no \\
\hline Collapse (b) & ves & yes & yes \\
\hline Stress & no & - & - \\
\hline Strain (c) & yes & yes & yes \\
\hline Other Measurements $(d)$ & yes & yes & yes \\
\hline
\end{tabular}

(a) CLIPER/CORTEX in emplacement hole.

(b) CLIPER/EXCOR in emplacement hole.

(c) On emplacement pipe.

(d) Sensitive pressure and radiation.

Event Personnel

Containment Physics
B. Hudson
V. Wheeler
LLNL
J. Kalinowski
LLNL
EG\&G/AVO
T. Stubbs
EG\&G/AVO

Instrumentation

$\begin{array}{ll}\text { J. Mercier } & \text { LLNL } \\ \text { T. Brown } & \text { EG\&G/AVO } \\ \text { R. Spilsbury } & \text { EG\&G/NVO } \\ \text { A. Moeller } & \text { EG\&G/NVO }\end{array}$


Contents

1. Event Description

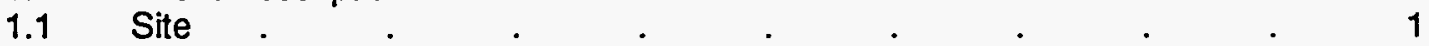

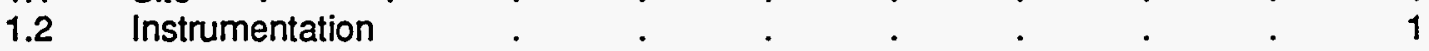

2. Plug Emplacement

2.1 Pipe strain . . 8

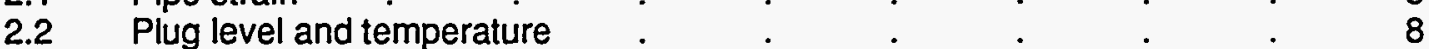

3. Stemming Performance

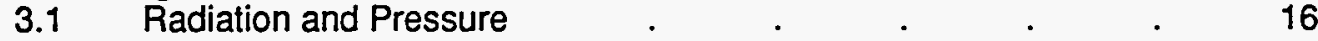

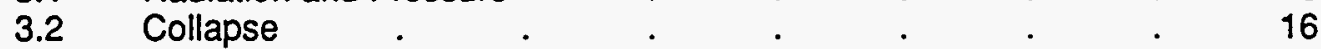

3.3 Motion near the top of the emplacement hole $\quad$. $\quad$. $\quad 17$

4. Other Measurements

4.1 Behavior of the recording trailer . $\quad . \quad$. . . 40

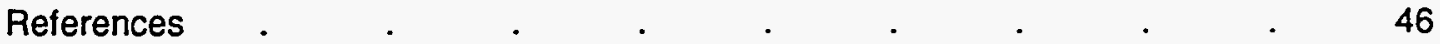




\section{Event Descriotion}

The BODIE device was detonated at 16:00:16 PST on the afternoon of December 13, 1986. Sub-surface collapse occurred about 12 hours later.

Low-level radiation was detected above ground beginning about 3 days after the event(1). However, the source of this radiation was not positively determined and no exposures were received and no radiation was detected beyond the boundaries of the test site. Containment was considered satisfactory.

\section{Site}

The BODIE device was located in hole U20ap of the Nevada Test Site (NTS) as indicated in Figure 1.1. The device was buried at a depth of $635 \mathrm{~m}$ in ash-flow tuff, about $20 \mathrm{~m}$ above the standing water level (SWL). A plan view of the local area is shown in Figure 1.2 and the geologic cross sections through U20ap are shown in Figure 1.3(2). Figure 1.4 shows the asbuilt stemming plan for the $2.44 \mathrm{~m}$ diameter hole. A log of the stemming operations was maintained by Holmes and Narver(3).

\subsection{Instrumentation}

A history of the fielding operations of the instrumentation is given in Reference 4. Details of the instrumentation set-up are given in Reference 5 and the as-built containment instrumentation plan is shown in Figure 1.5.

Each of the six sanded gypsum concrete (SGC) plugs was monitored during emplacement with arrays of conductivity and temperature probes, and the coarse stemming on either side of the central four SGC plugs was instrumented for pressure and radiation. Data from each plug region were transmitted up-hole in analog form and recorded on magnetic tape. Each of the standard pressure and radiation (pxra) stations, except the deepest, was accompanied by another such station having greater sensitivity. In the case of the radiation, the sensitivity was increased by about a factor of 100 . A separation of about $3 \mathrm{~m}$ was required between the stations to prevent the sensitive stations from detecting the radiation emitted from the background source chips in the standard stations. A sensitive station was also fielded $15.24 \mathrm{~m}$ from SGZ, buried at a depth of $.61 \mathrm{~m}$ 
Hydrodynamic yield of the device as well as chimney formation were monitored by a pair of EXCOR sensor cables and three CORTEX sensors cables. Results of the hydrodynamic yield measurements are reported elsewhere(6).

Vertical motion was monitored in each of the stemming pressure and radiation stations. Motion stations were also fielded in the ground surface ( $0.91 \mathrm{~m}$ depth) at a horizontal range of $15.4 \mathrm{~m}$ from surface ground zero and in the recording trailer. 


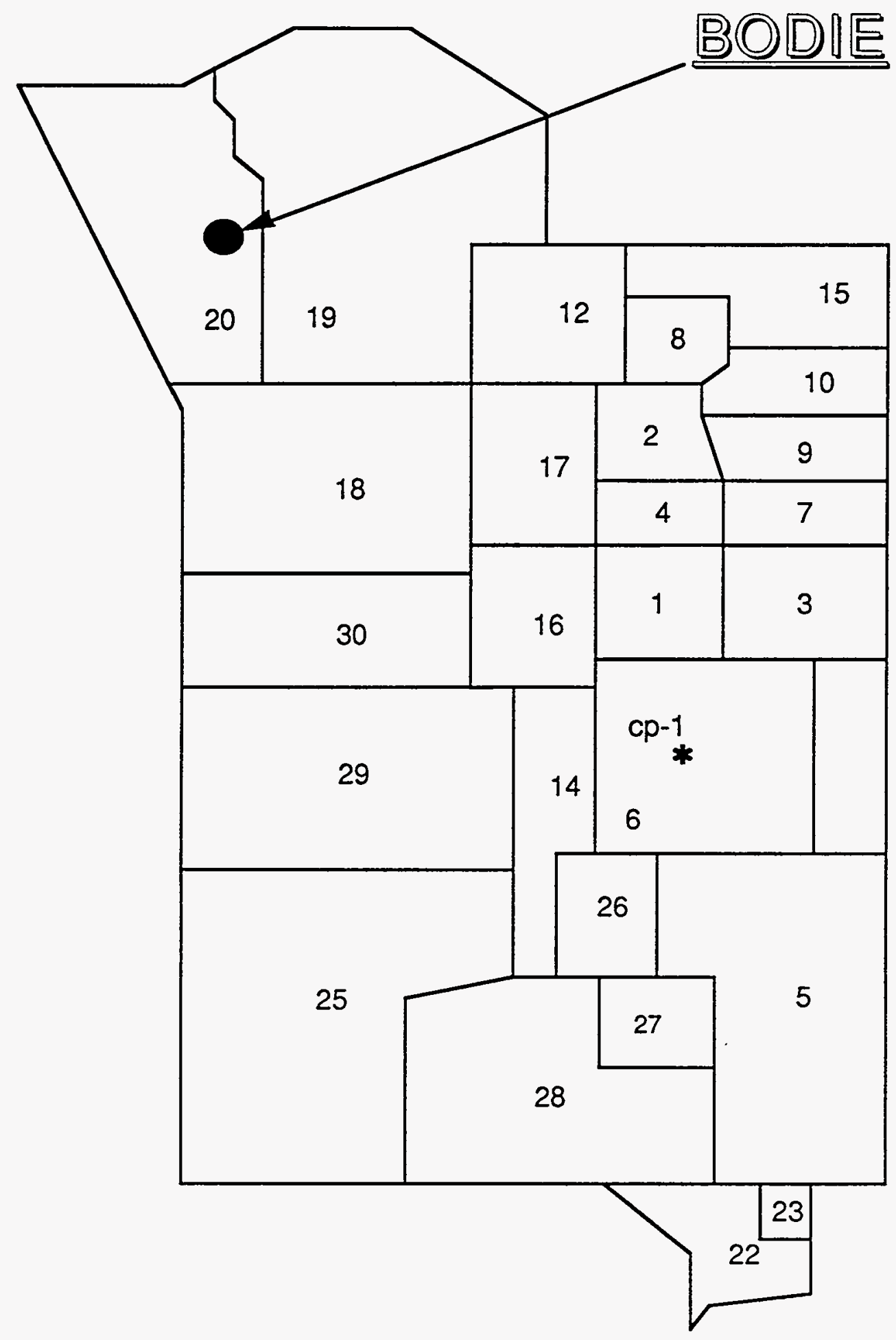

Figure 1.1 Map of the Nevada Test Site showing the position of BODIE. 


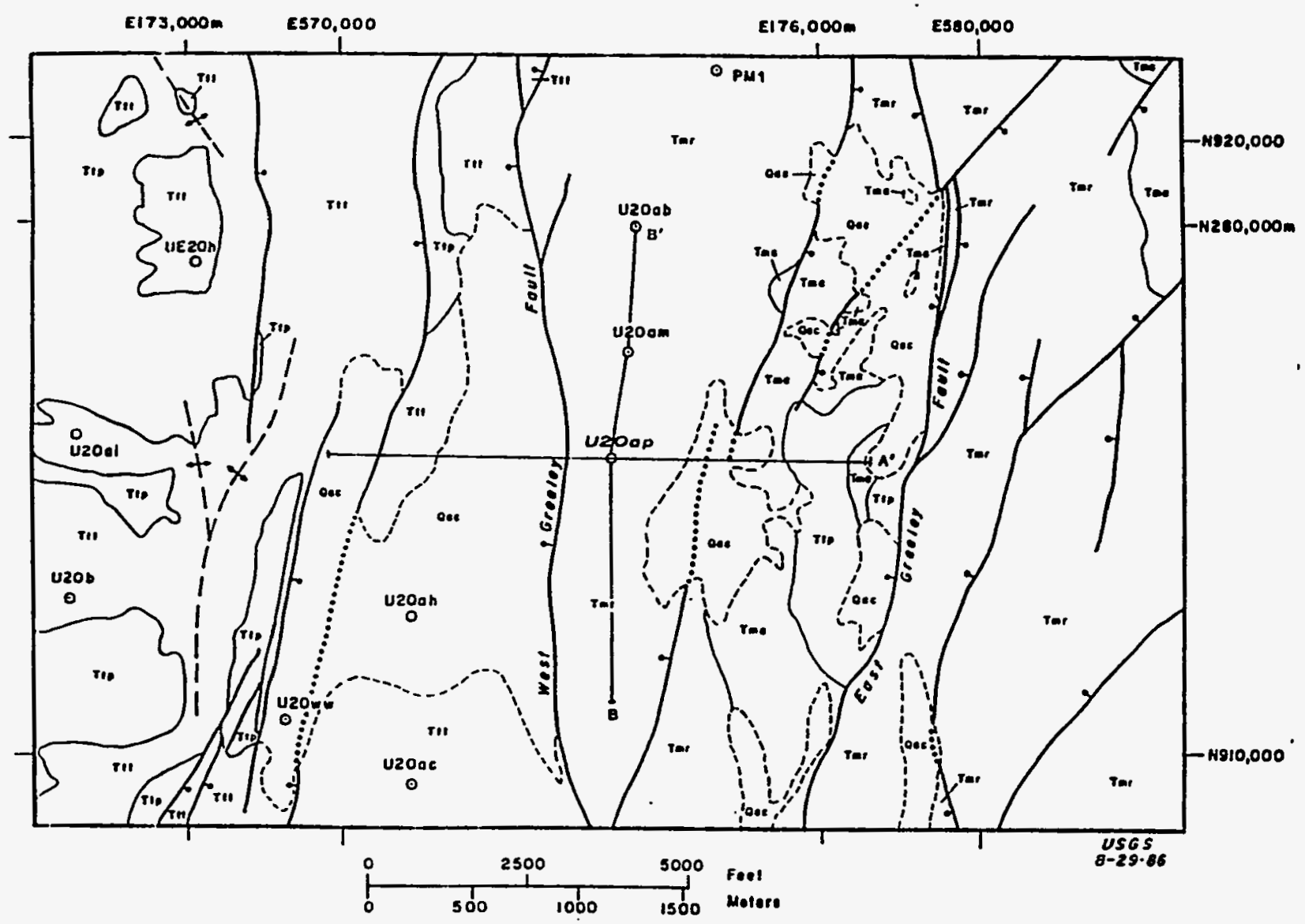

SYMBOLS USED ON THE GEOLOGIC MAP AND CROSS SECTIONS

QUATERNARY

Qac Alluvium

TERTIARY

Ttt Trail Ridge Member, Thirsty Canyon Tuff

Ttp Pahute Mesa Member, Thirsty Canyon Tuff

Ttr Rocket Wash Member, Thirsty Canyon Tuff

Tma Ammonia Tanks Member, Timber Mountain Tuff

Tmr Rainier Mesa Member, Timber Mountain Tuff

Tp(Tb) Bedded tuff associated with Paintbrush Tuff

Tpr Rhyolite lava, Pre-Pah Canyon Rhyolite Lavas

Trab Bedded and ash-flow tuff, Tuffs and Rhyolites of Area 20

Trau Upper Rhyolite Lavas, Tuffs and Rhyolites of Area 20

Tra Tuffs and Rhyolites of Area 20, Undivided

Figure 1.2 Geologic plan map for the cross-sections through Hole U20ap (Figure 1.3). 


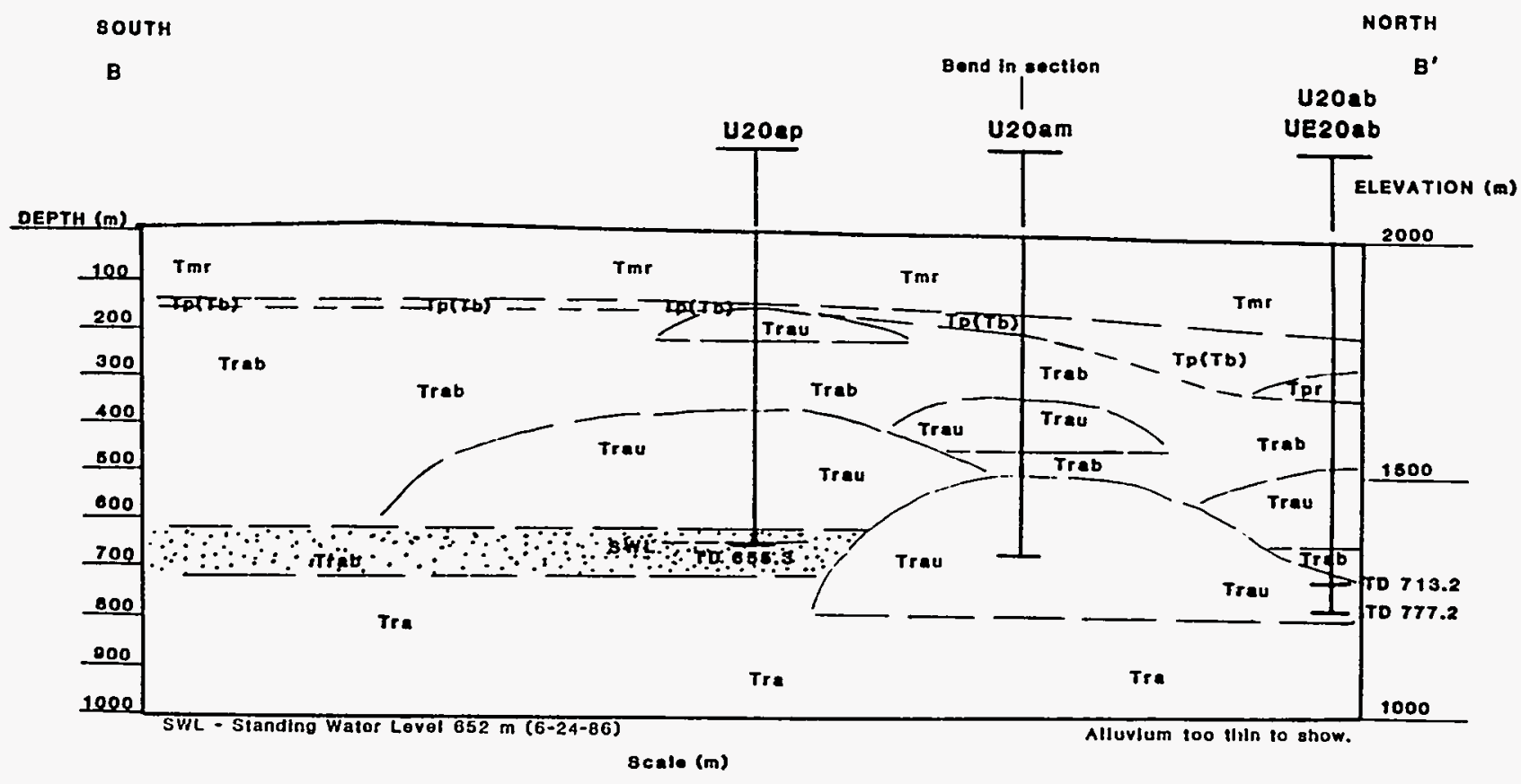

$0 \quad 100 \quad 200 \quad 300 \quad 400800$

NORTH-SOUTH CROSS SECTION U2OAP

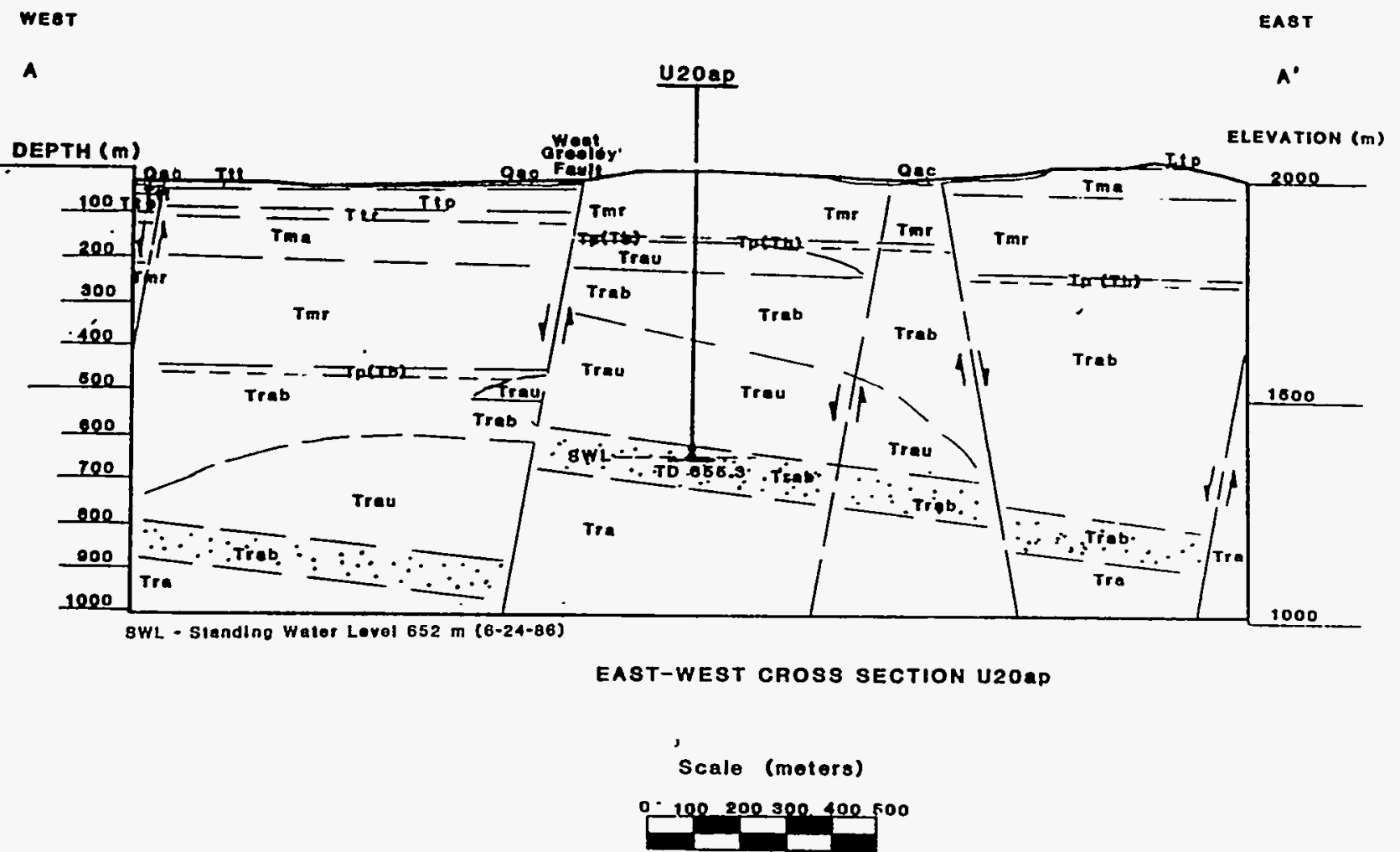

Figure 1.3 Geologic cross sections through Hole U20ap. 


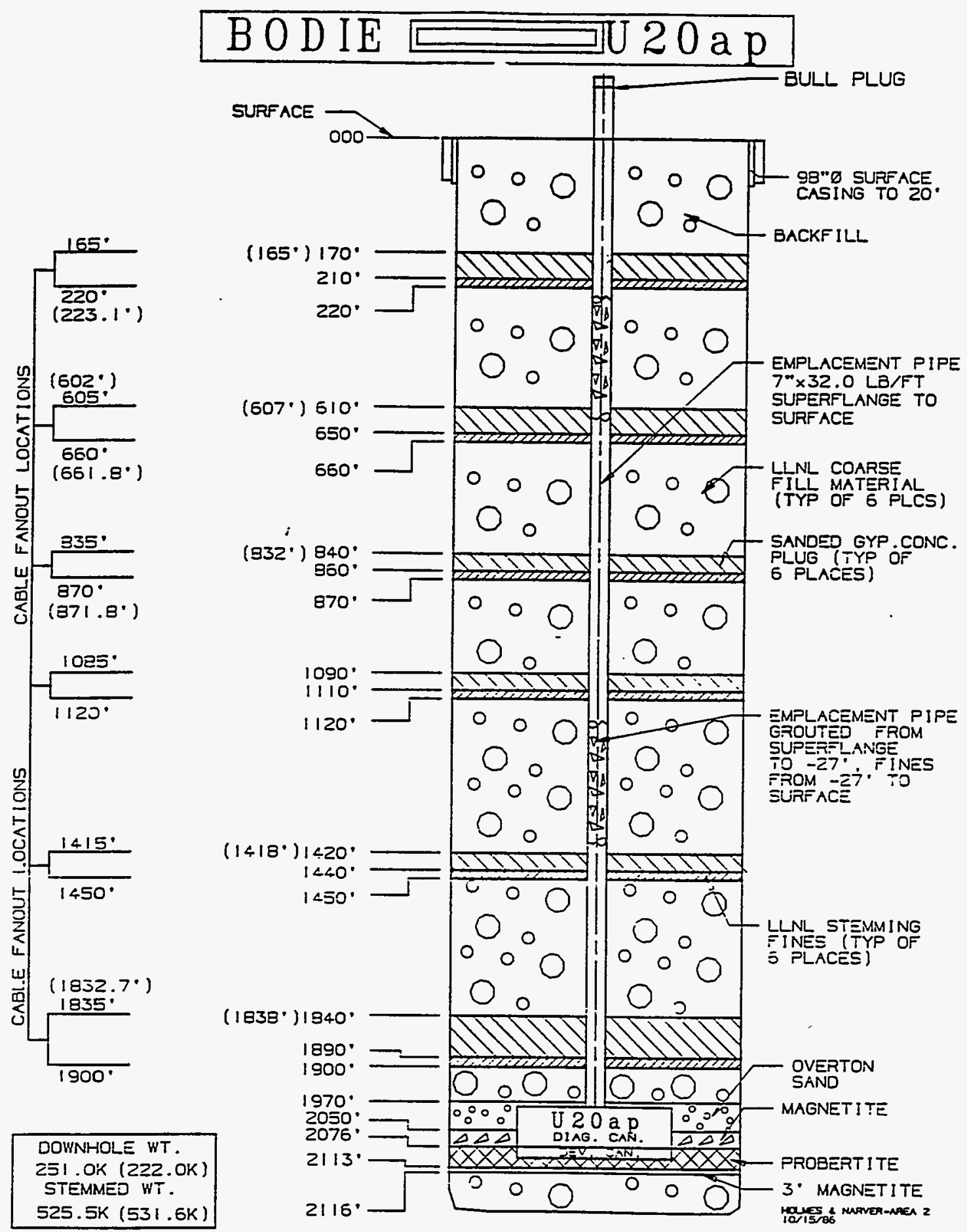

Figure 1.4 As-built Stemming plan for Hole U20ap. 


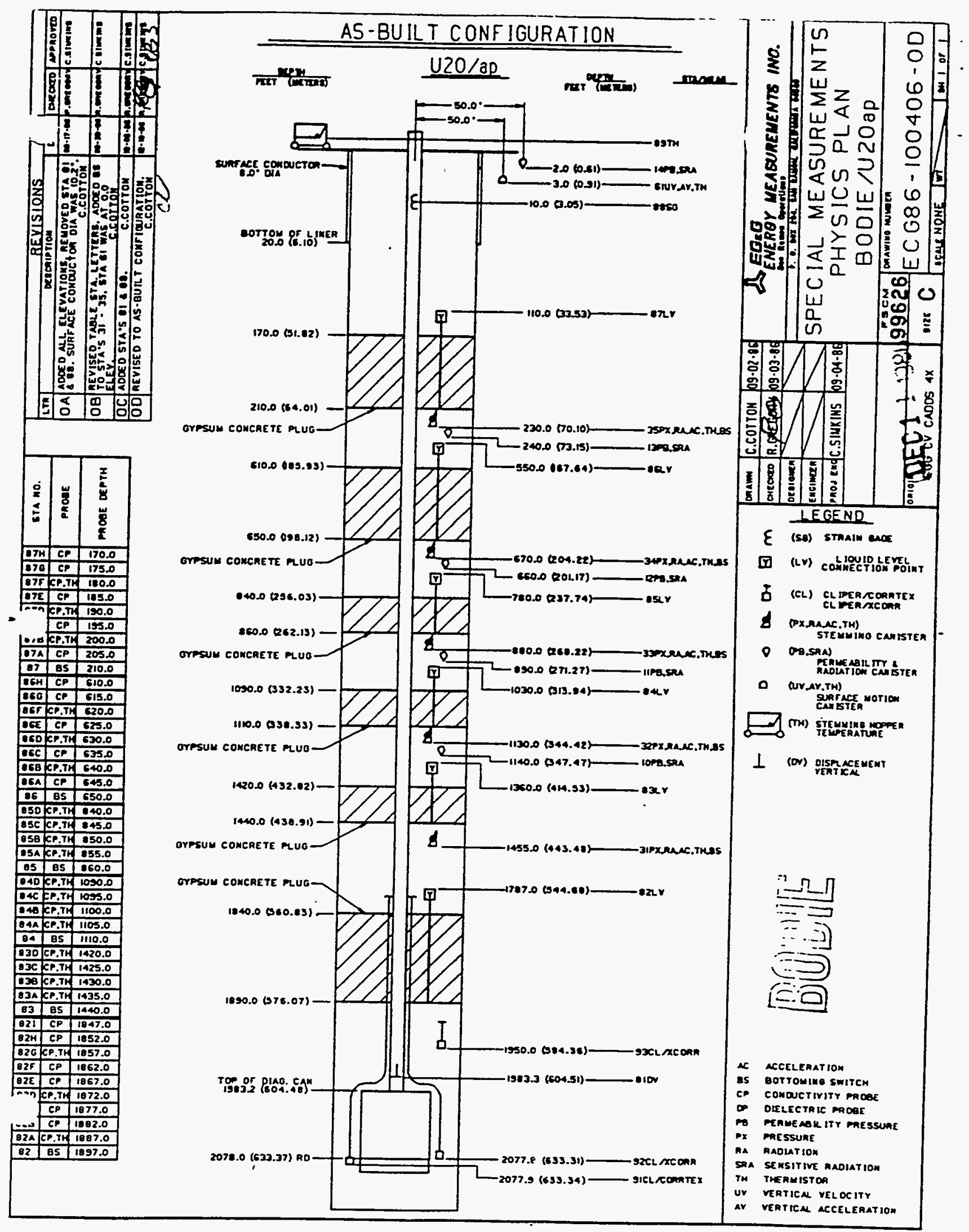

Figure 1.5 As-built Containment Instrumentation Plan for BODIE event. 


\section{Plug Emplacement}

\subsection{Pipe strain}

The load on the emplacement pipe was monitored during stemming by a strain gauge (Station 88) mounted near the top of the pipe. The history of this transducer is shown in figure 2.1.

\subsection{Plug level and temperature}

The emplacement of each of the six SGC plugs was monitored with an array of conductivity probes and thermistors. The locations of the probes are shown in Figure 1.5. Figures 2.2- 2.7 contain plots of the arrival times of the SGC as a function of depth, as determined from the conductivity probes (filled circles), and SGC temperature histories. Temperatures of the plugs were measured at the probes indicated in each Figure. The upper and lower boundary positions of the plugs were determined by tag line measurements (open circles).

These data indicate that all plugs were emplaced as planned. 


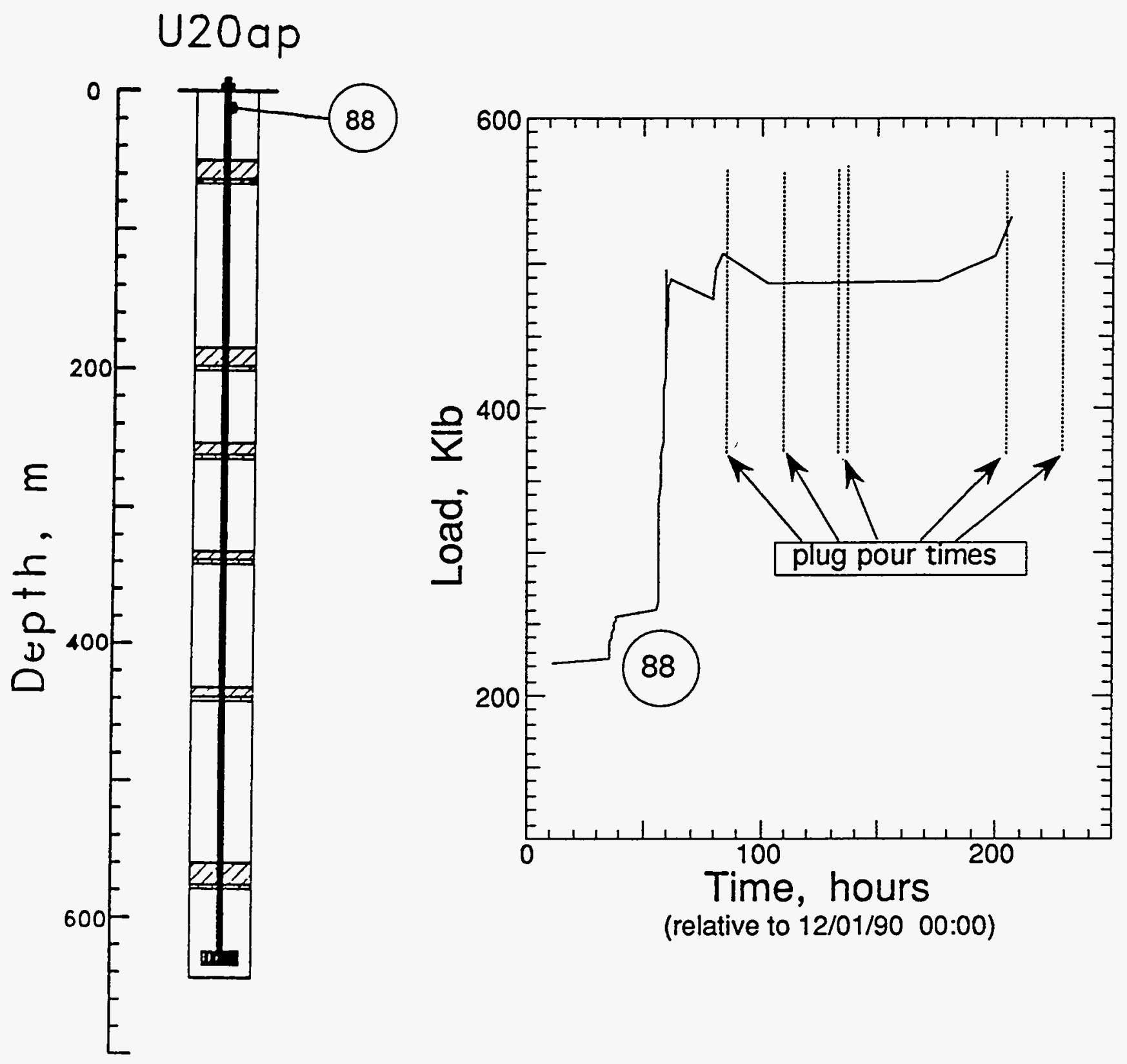

Figure 2.1 Load history of top of the emplacement pipe (Station 88). 


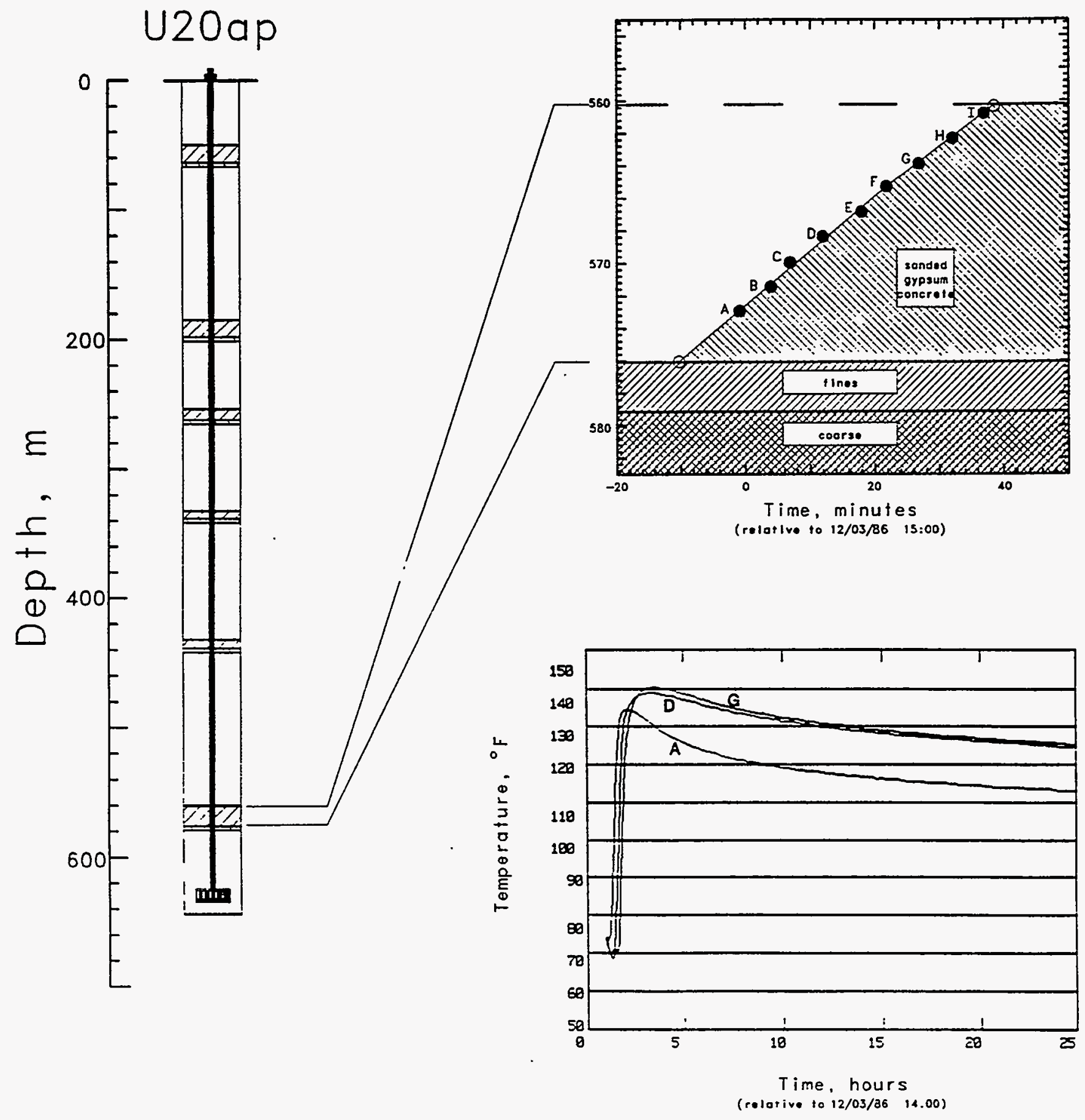

Figure 2.2 Emplacement diagnostics data from SGC plug at $560 \mathrm{~m}$ depth. The upper and lower boundaries of the plug were determined with a tag line (open symbols).

Probes $A, D$, and $G$ included temperature sensors. 


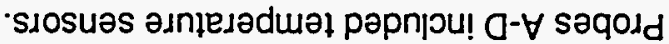

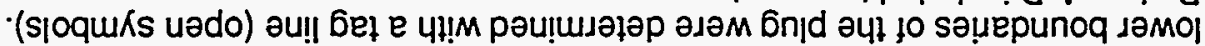

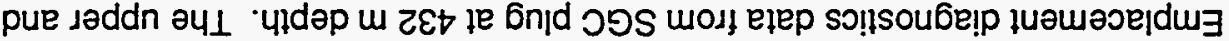

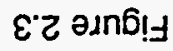
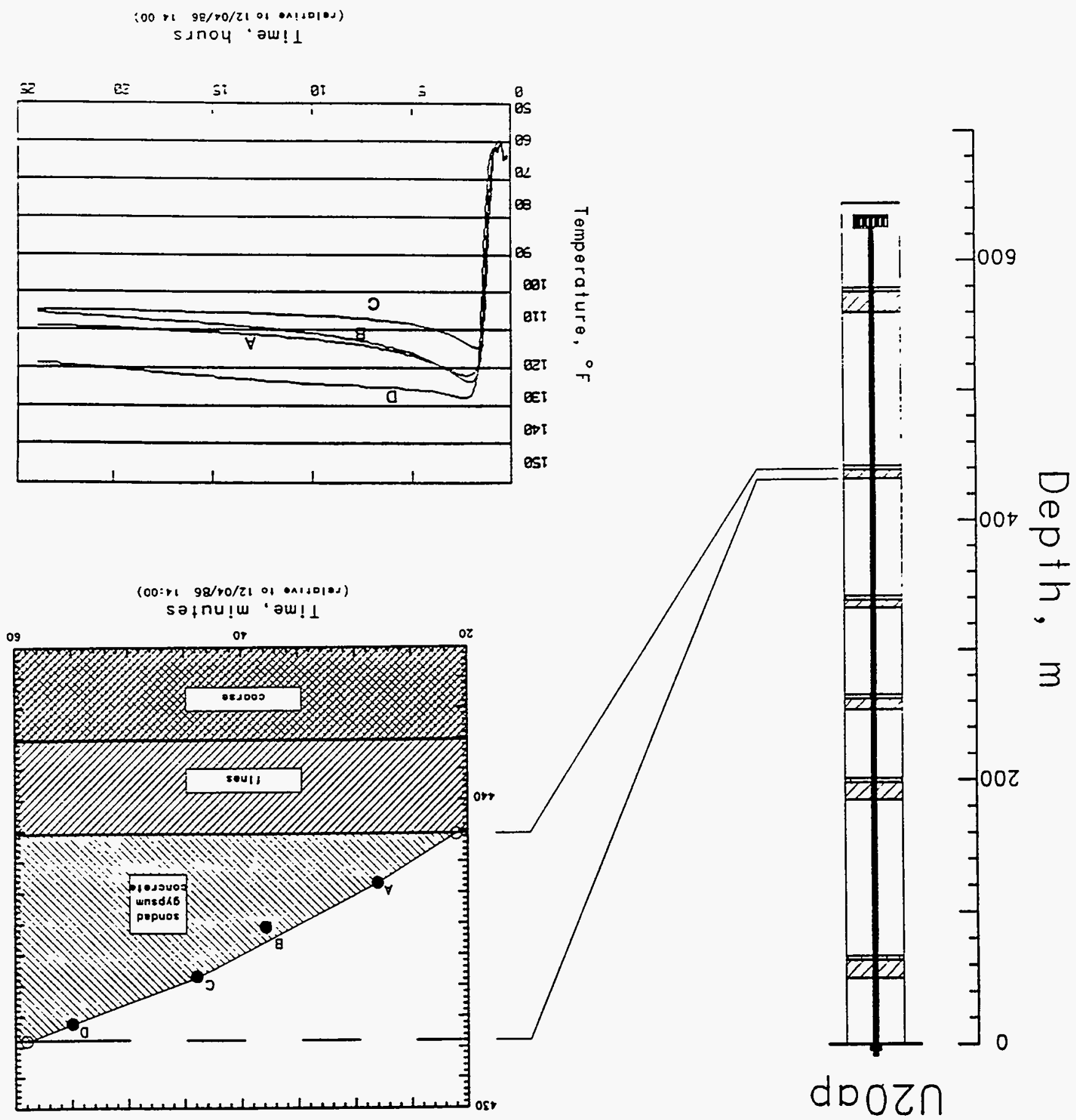

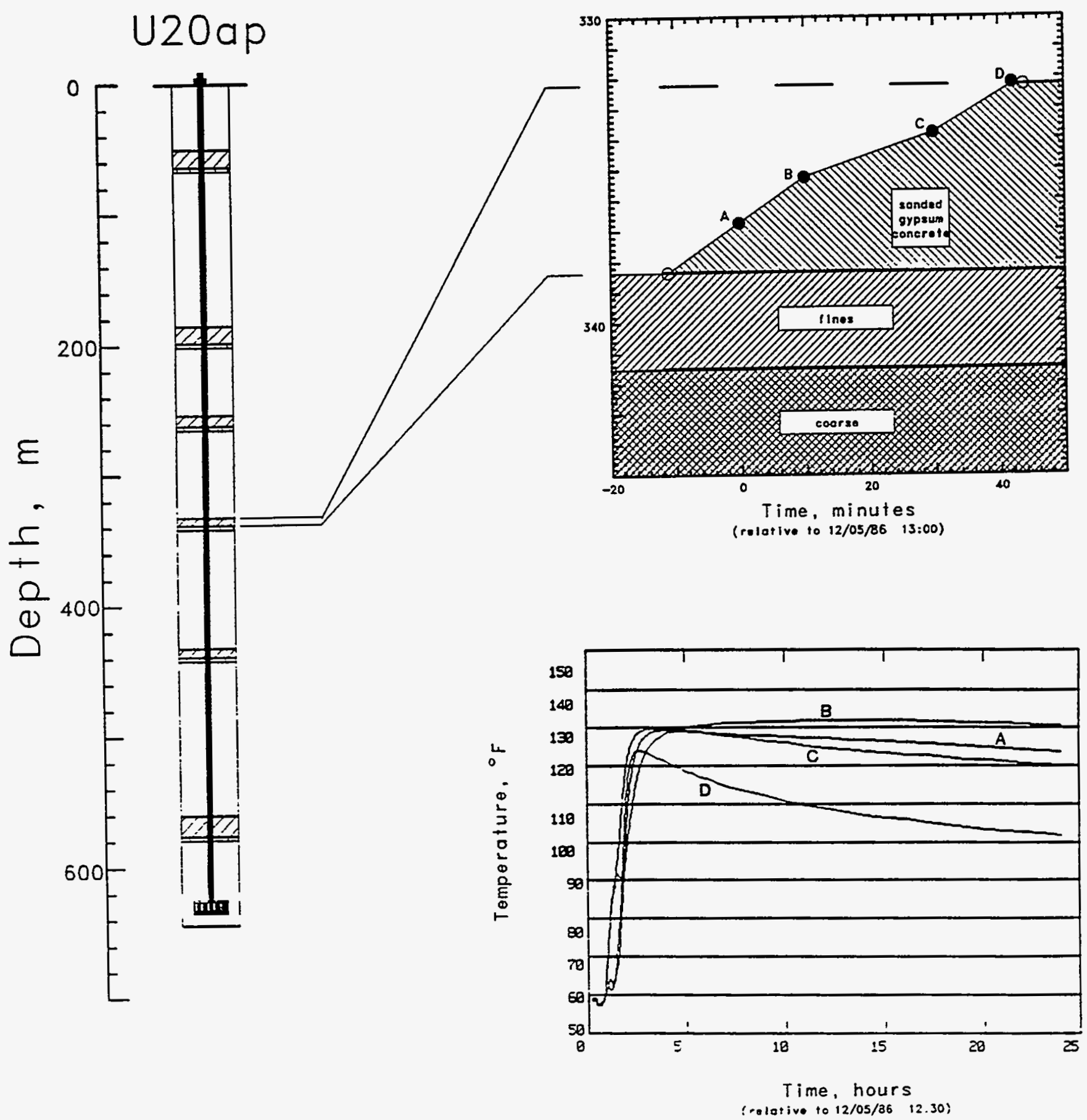

Figure 2.4 Emplacement diagnostics data from SGC plug at $332 \mathrm{~m}$ depth. The upper and lower boundaries of the plug were determined with a tag line (open symbols). Probes A-D included temperature sensors. 


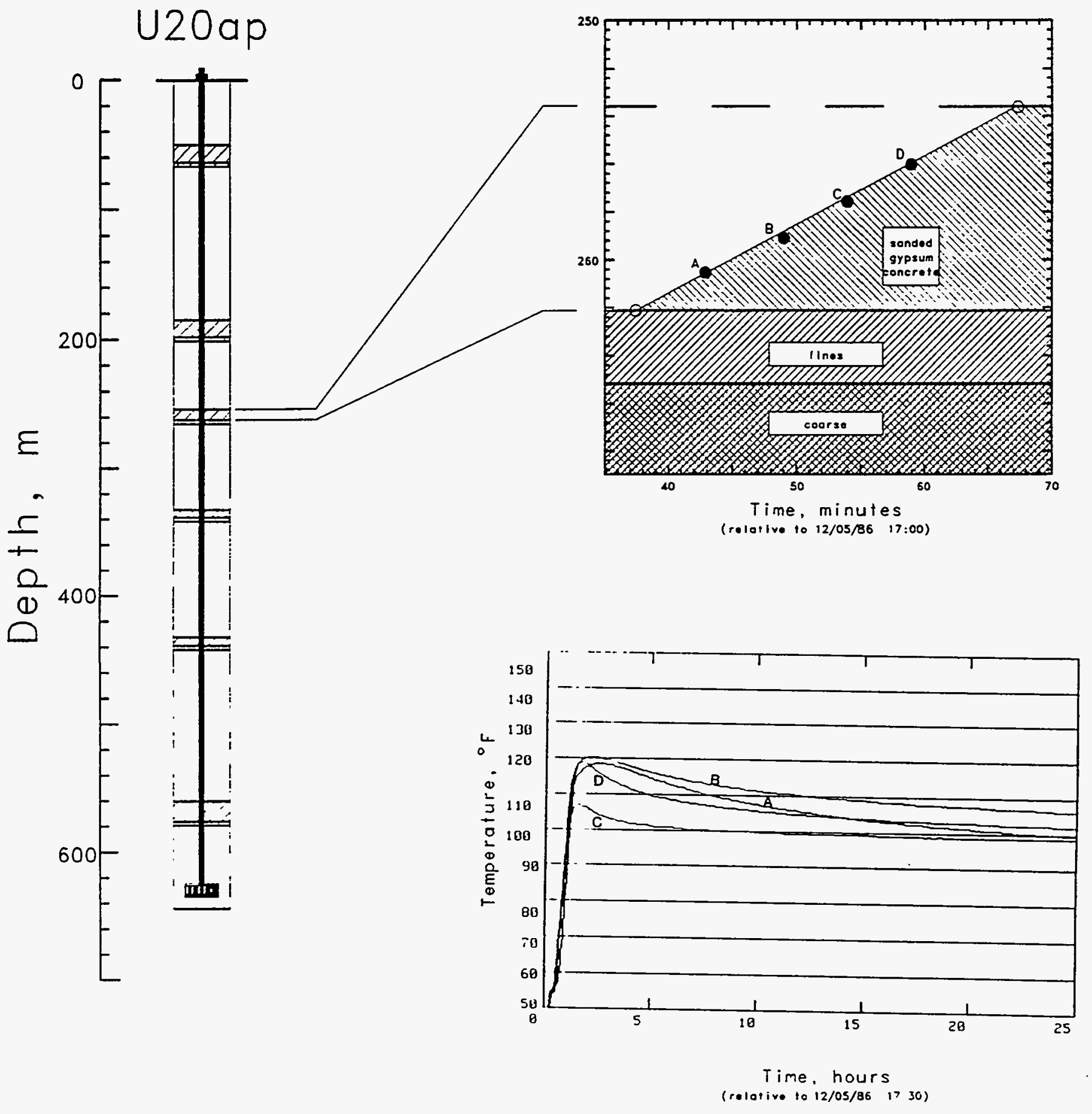

Figure 2.5 Emplacement diagnostics data from SGC plug at $254 \mathrm{~m}$ depth. The upper and lower boundaries of the plug were determined with a tag line (open symbols).

Probes A-D included temperature sensors. 


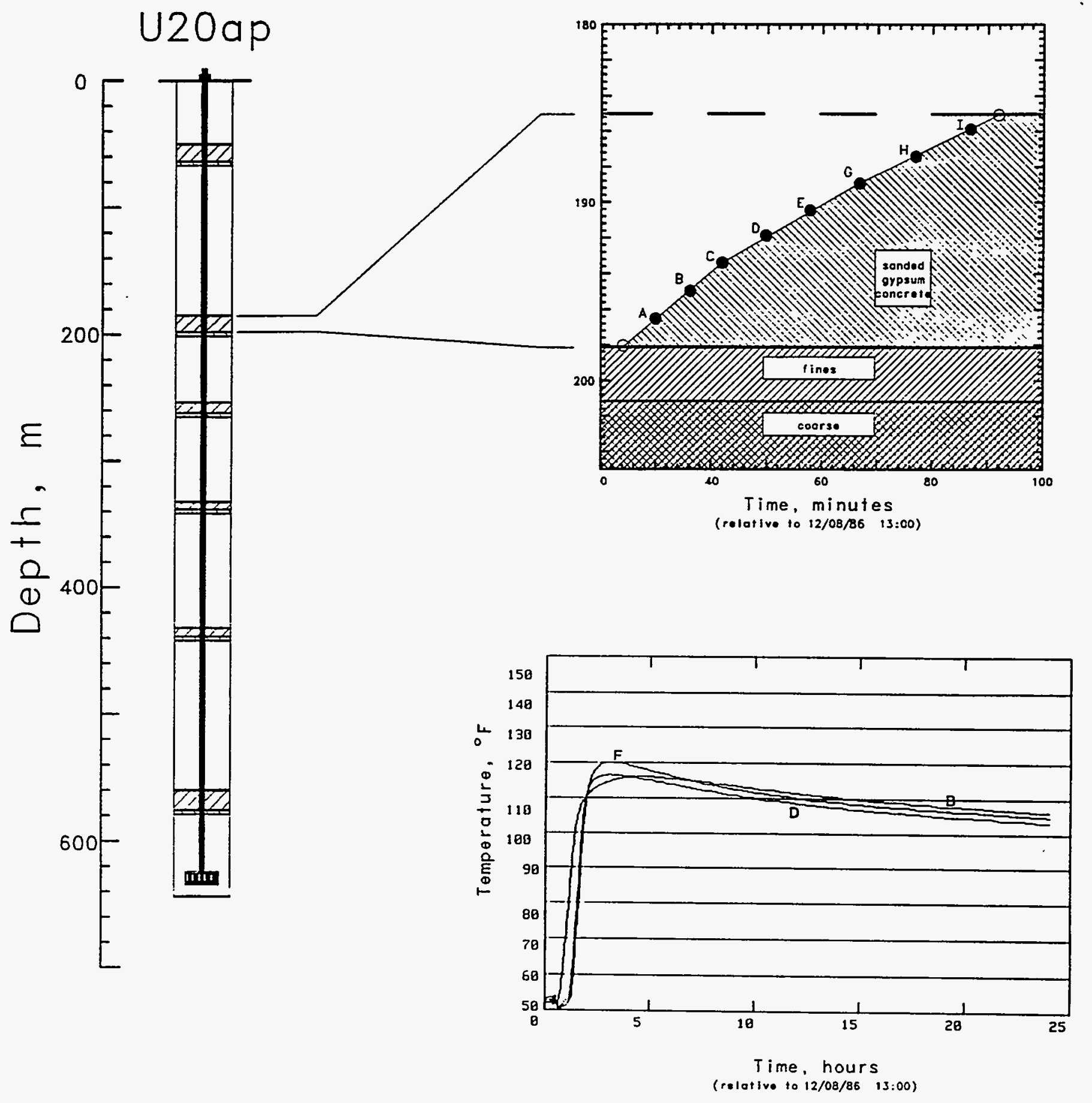

Figure 2.6 Emplacement diagnostics data from SGC plug at $185 \mathrm{~m}$ depth. The upper and lower boundaries of the plug were determined with a tag line (open symbols). Probes $B, D$, and $F$ included temperature sensors. 


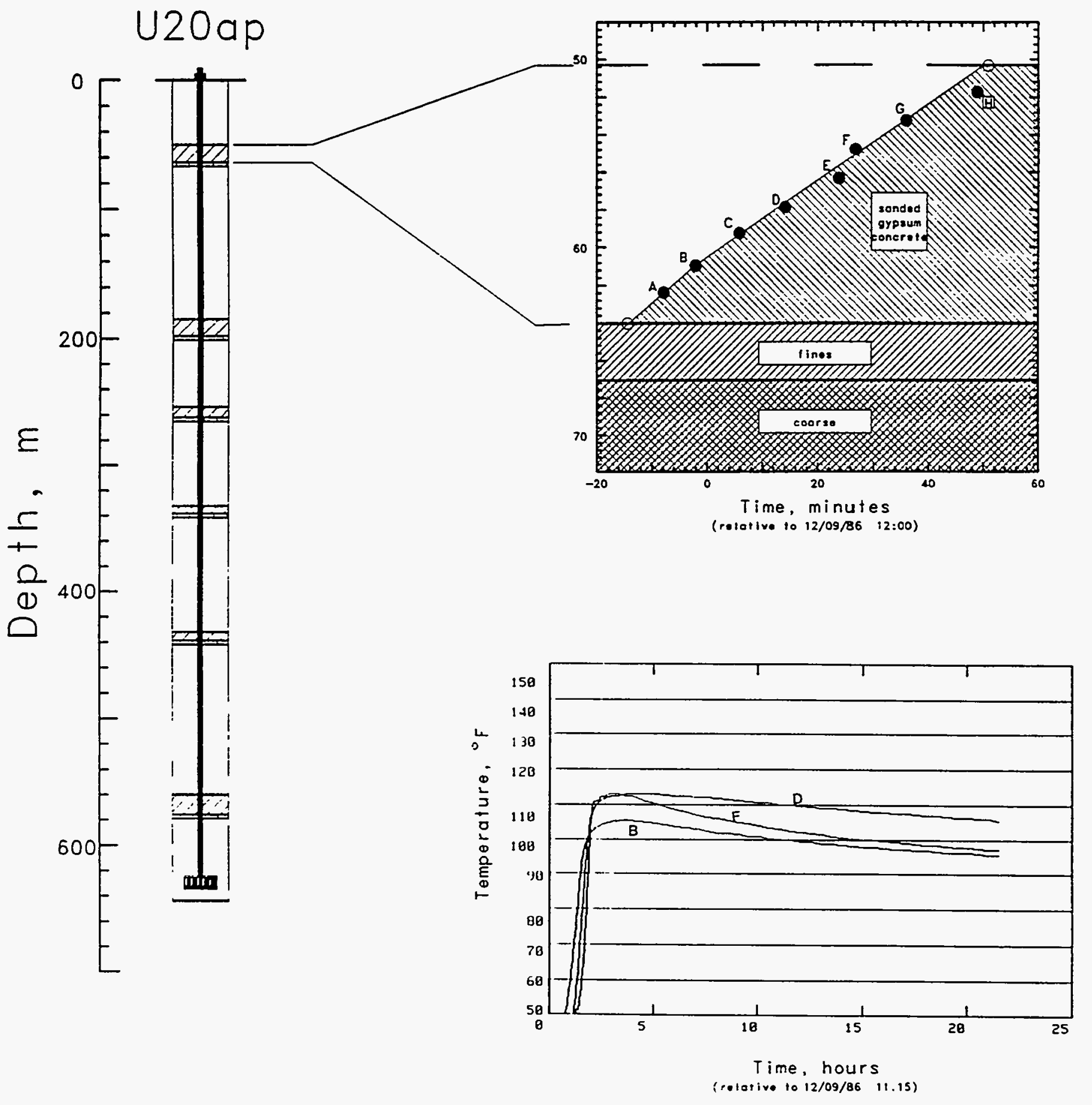

Figure 2.7 Emplacement diagnostics data from SGC plug at $50 \mathrm{~m}$ depth. The upper and lower boundaries of the plug were determined with a tag line (open symbols). Probes $B$, $D$, and $F$ included temperature sensors. 


\section{Stemming Performance}

\subsection{Pressure and Radiation}

Pressure and radiation histories obtained from the BODIE stemming are shown in Figures 3.1 through 3.6. The pressure wave forms from the standard gauges and the sensitive transducers are identical with slight scale differences being due to calibration except for the twin stations 13 and 35 (Figure 3.5).

Figure 3.7 compares the long-term atmospheric pressure histories measured in the emplacement hole (Stations 11, 12, and 13) with that measured in the ground surface (Station 14). Station 10 is not represented since the large pressure change (Figure 3.2) at about 12 hours obscures the later small fluctuations due to atmospheric changes.

A very low-level radiation emission was detected beginning 3 days after the event(1) emanating from surface cracks that were more than $360 \mathrm{~m}$ from SGZ. BODIE was probably the source of this radiation. However, no exposures were received and no radiation was detected beyond the boundaries of the test site. Containment was considered to be satisfactory.

\subsection{Collapse}

Until the time of subsurface collapse at about +11.8 hours, there was no detectable radiation in the emplacement hole. At this time Station 31 was lost after dropping to a pressure of 2 psia, Stations 10 and 32 registered an abrupt pressure drop to about 1 psia followed by a long subsequent recovery. At about +11.8 hours, a radiation increase that was too low to be registered by the standard transducer (Station 32) was observed by the sensitive detector (Station 10). At about +66 hours, a second minor pulse of radiation was seen by both Stations 10 and 32 with no measurable pressure change. The EXCOR cables registered adjustments in the stemming column at these times and indicated that all collapse terminated at or below Plug 3. All of these features are shown in Figure 3.8. No radiation was observed in the stemming above Plug 3.

Figure 3.9 is a composite of all the pressures measured down-hole on the sensitive transducers. The pressure perturbation due to collapse below Plug 3 is seen to diffuse up the emplacement hole with all evidence of it gone above Plug 5 (at Station 13). 


\subsection{Motion}

\subsubsection{Explosion-induced motion}

The measured and derived explosion-induced motions from the transducers fielded in or near the emplacement hole are summarized in Table 3.1. Tables 3.2 and 3.3 give the transducer characteristics of these gauges.

All down-hole motion transducers performed as planned except for the accelerometer in Station 32. The bottoming switch (which locates the station with respect to the stemming during the stemming operation) failed and thus this station was not properly installed in a vertical orientation and the data from this station are highly suspect.

A major disruption of the recorded signals for the data taken in the high-level end of Trailer 983 occurred between 1.2 and 1.4 seconds (at the time of slap-down), with many subsequent noise spikes, invalidating the integrals of the motion at later times. This effected Stations 61 and 71 (see Section 4).

Wave forms of all of the measured and derived motions in or near the emplacement hole are presented in Figures 3.10 through 3.15. When there is more than one wave form plotted in a figure, the one annotated by ' $a$ ' is derived from acceleration data from that station.

\subsubsection{Collapse-induced motion}

All of the wave forms, either measured or derived, resulting from collapse in the stemming column are presented in Figures $3.16-3.20$. There was essentially no recoverable collapse motion above Plug 3 (Stations $33-35$ ), however, the signals are shown for completeness. Station 31 (below Plug 2 at $443.5 \mathrm{~m}$ depth) was lost at $+11: 48: 43$ after falling about $2 \mathrm{~m}$.

Station 32 (below Plug 3 at $344.4 \mathrm{~m}$ depth) was emplaced in a non-vertical orientation due to failure of the associated bottoming switch. The signal from the accelerometer at this station is unusable for magnitude, however it shows significant movement at $+11: 48: 50$. The character of the wave form strongly suggests that the canister was installed in a nearly horizontal orientation and, when the stemming fell away, came to a vertical orientation, suspended in free air at the end of the stretch cable. 

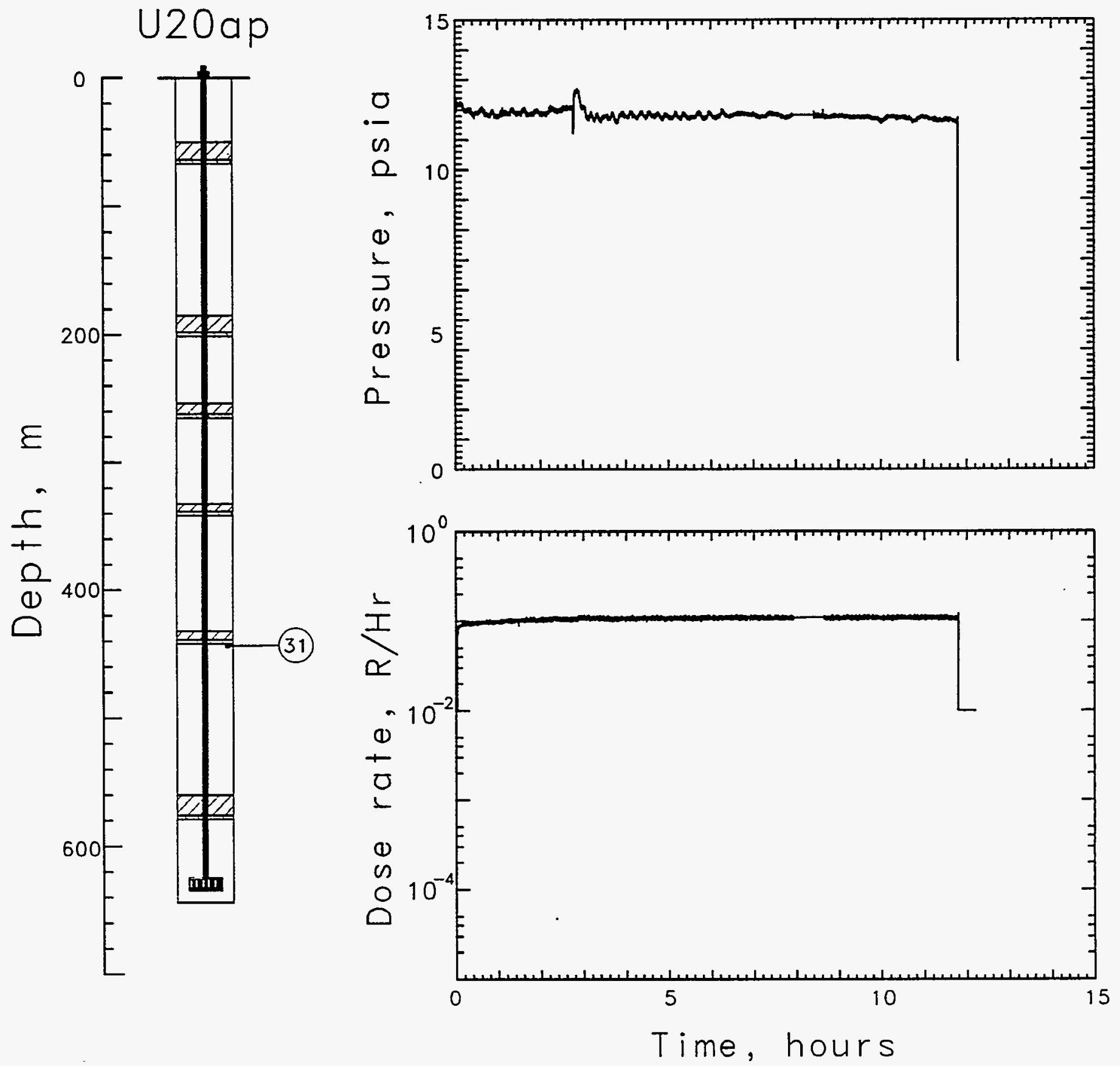

Figure 3.1 Pressure and radiation data from a depth of $443.5 \mathrm{~m}$ (Station 31, above plug 1). This station was lost at collapse. 

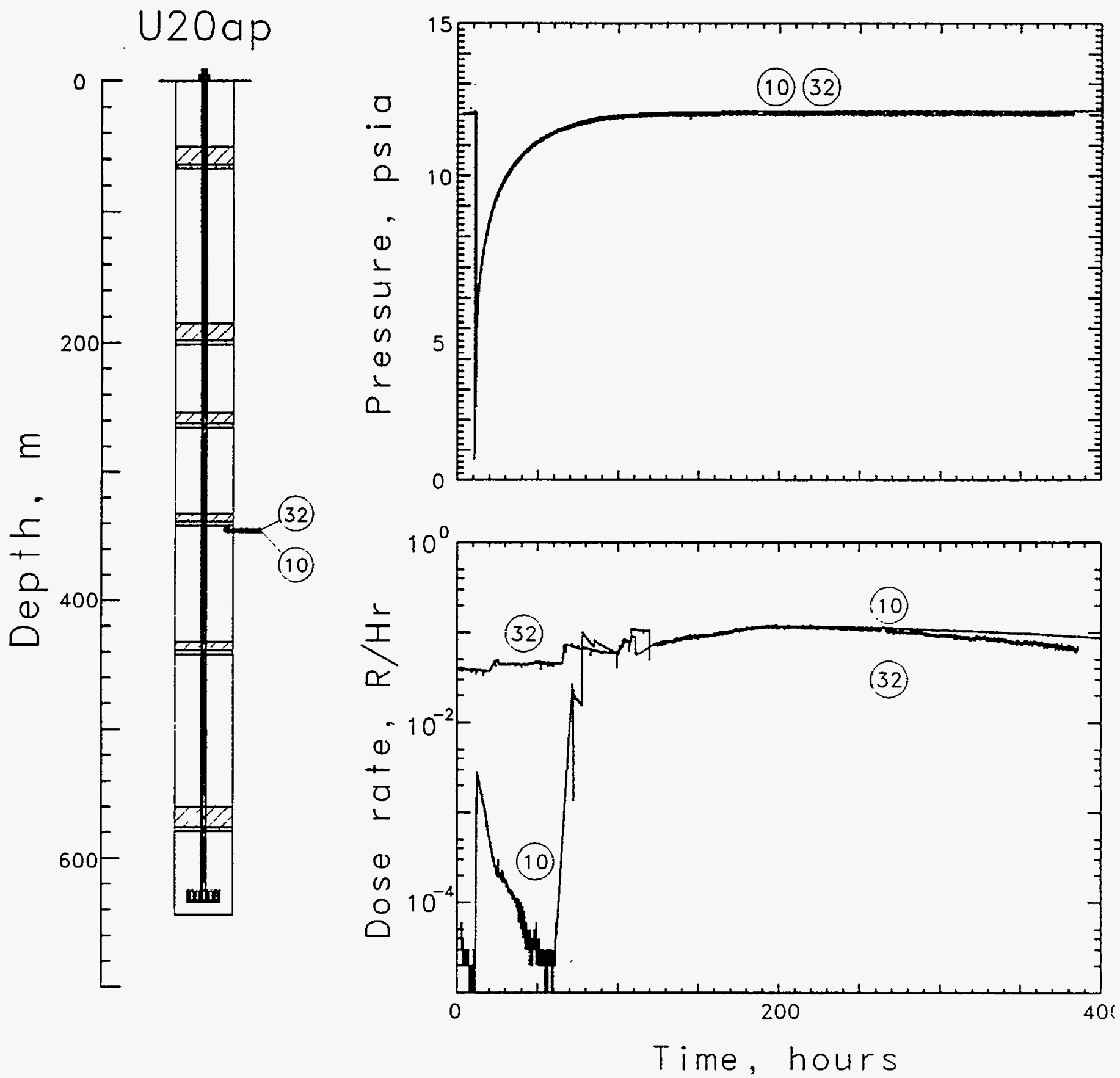

Figure 3.2 Pressure and radiation data from above Plug 2 (Station 10, at a depth of $347.7 \mathrm{~m}$ and Station 32, at a depth of $344.4 \mathrm{~m}$ ). 

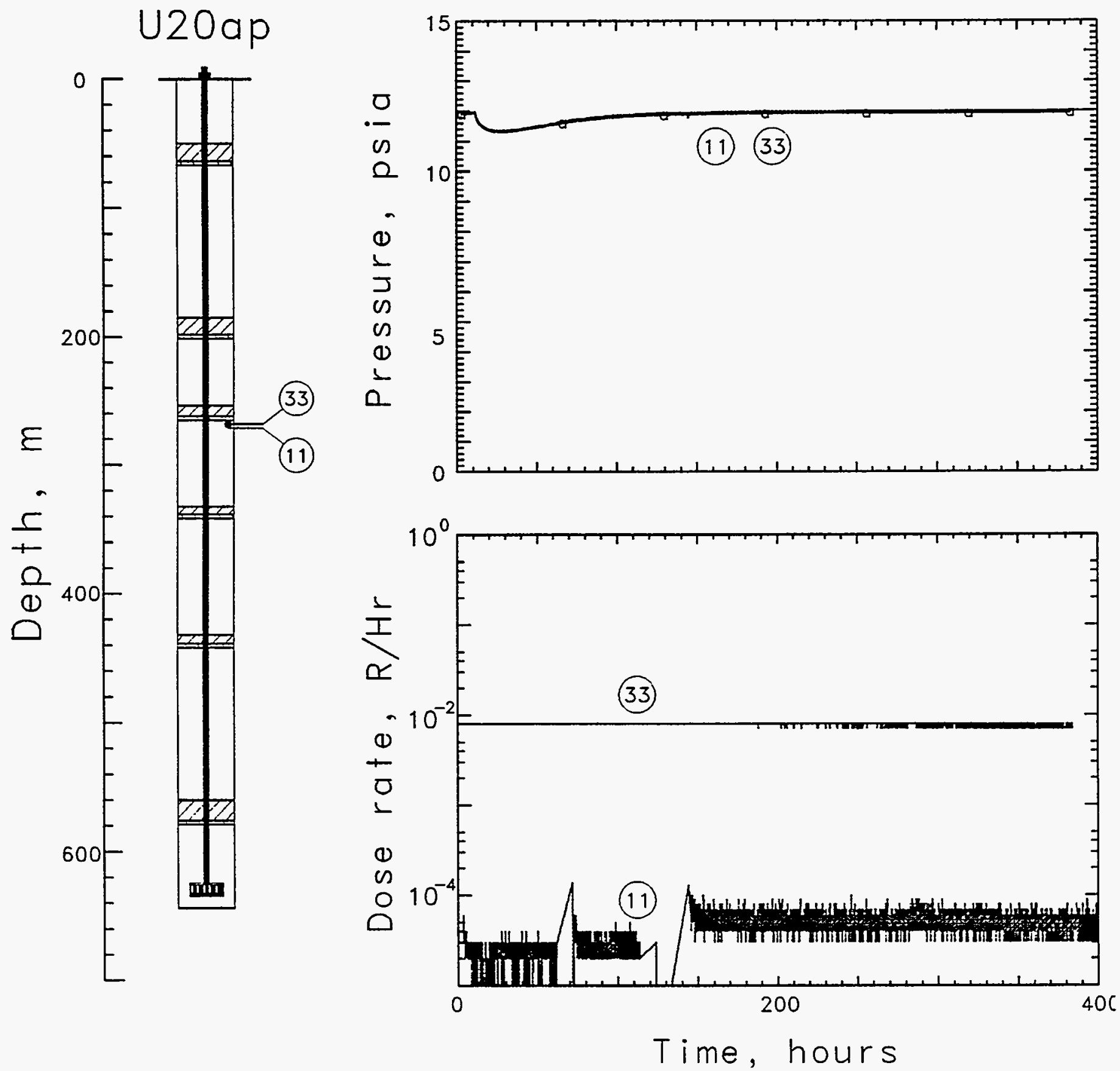

Figure 3.3 Pressure and radiation data from above Plug 3 (Station 11, at a depth of $271.3 \mathrm{~m}$ and Station 33, at a depth of $268.2 \mathrm{~m}$ ). 

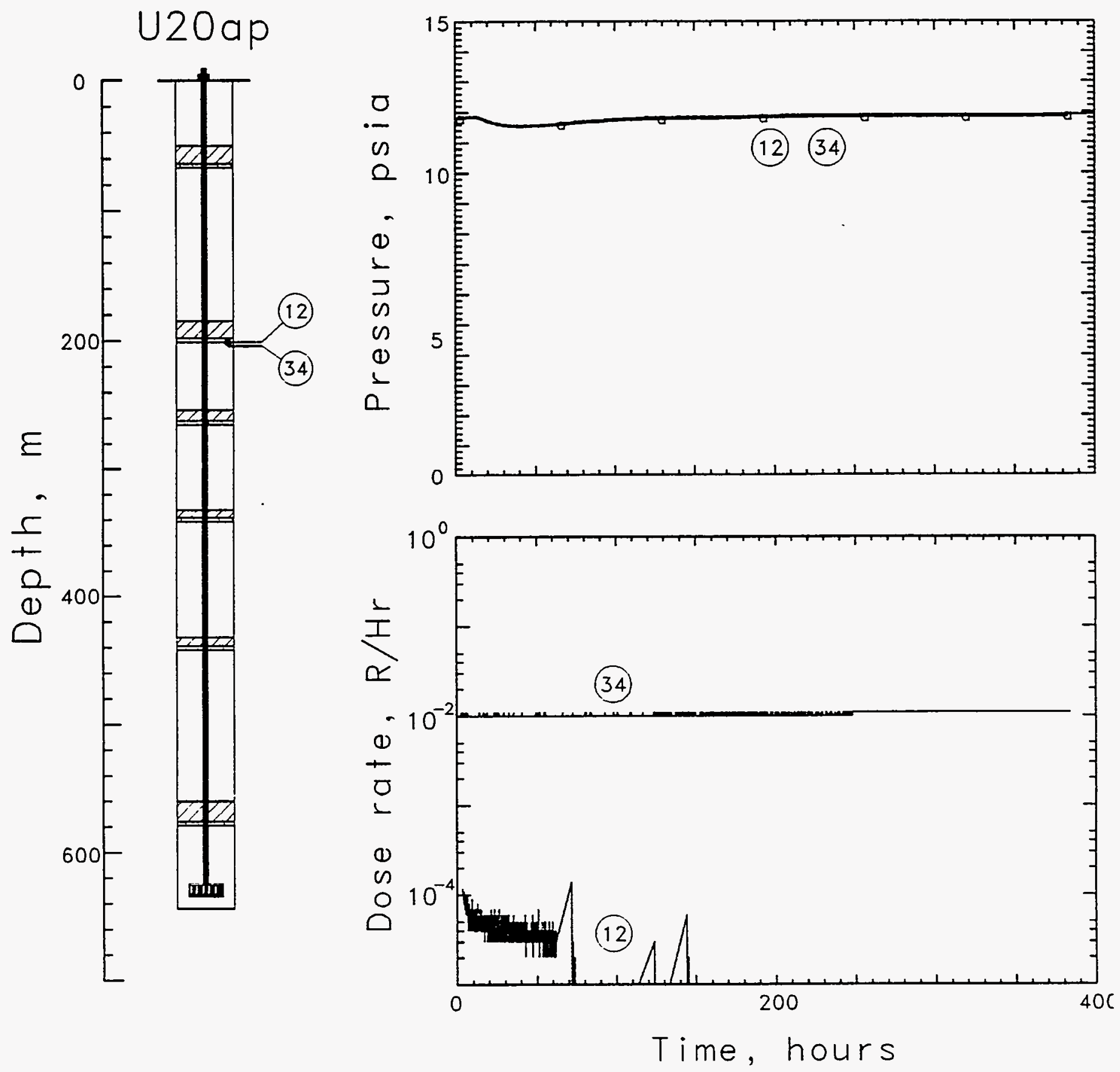

Figure 3.4 Pressure and radiation data from above Plug 4 (Station 12, at a depth of $201.2 \mathrm{~m}$ and Station 34, at a depth of $204.2 \mathrm{~m}$ ). 

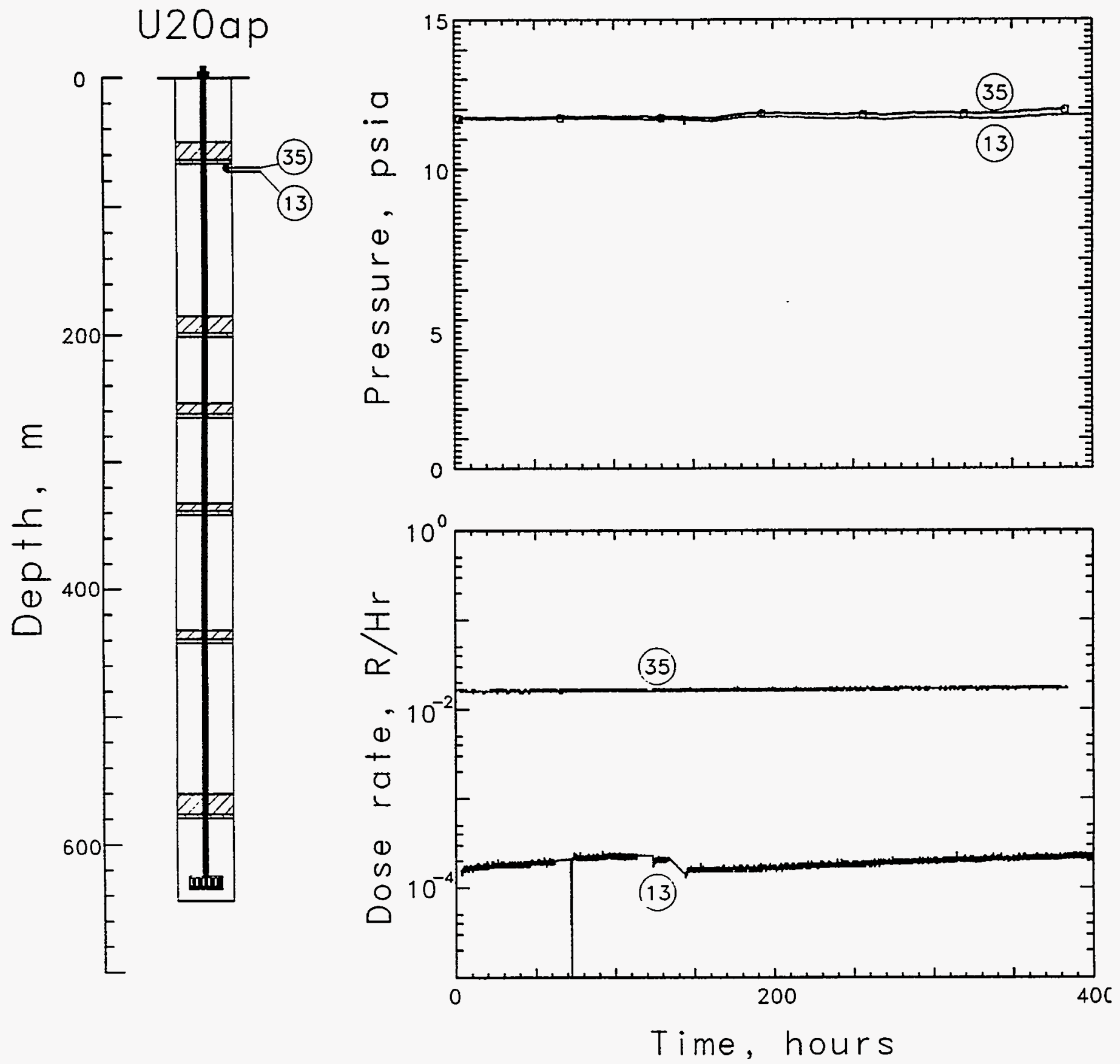

Figure 3.5 Pressure and radiation data from above Plug 5 (Station 13, at a depth of $73.2 \mathrm{~m}$ and Station 35, at a depth of $70.1 \mathrm{~m}$ ). 

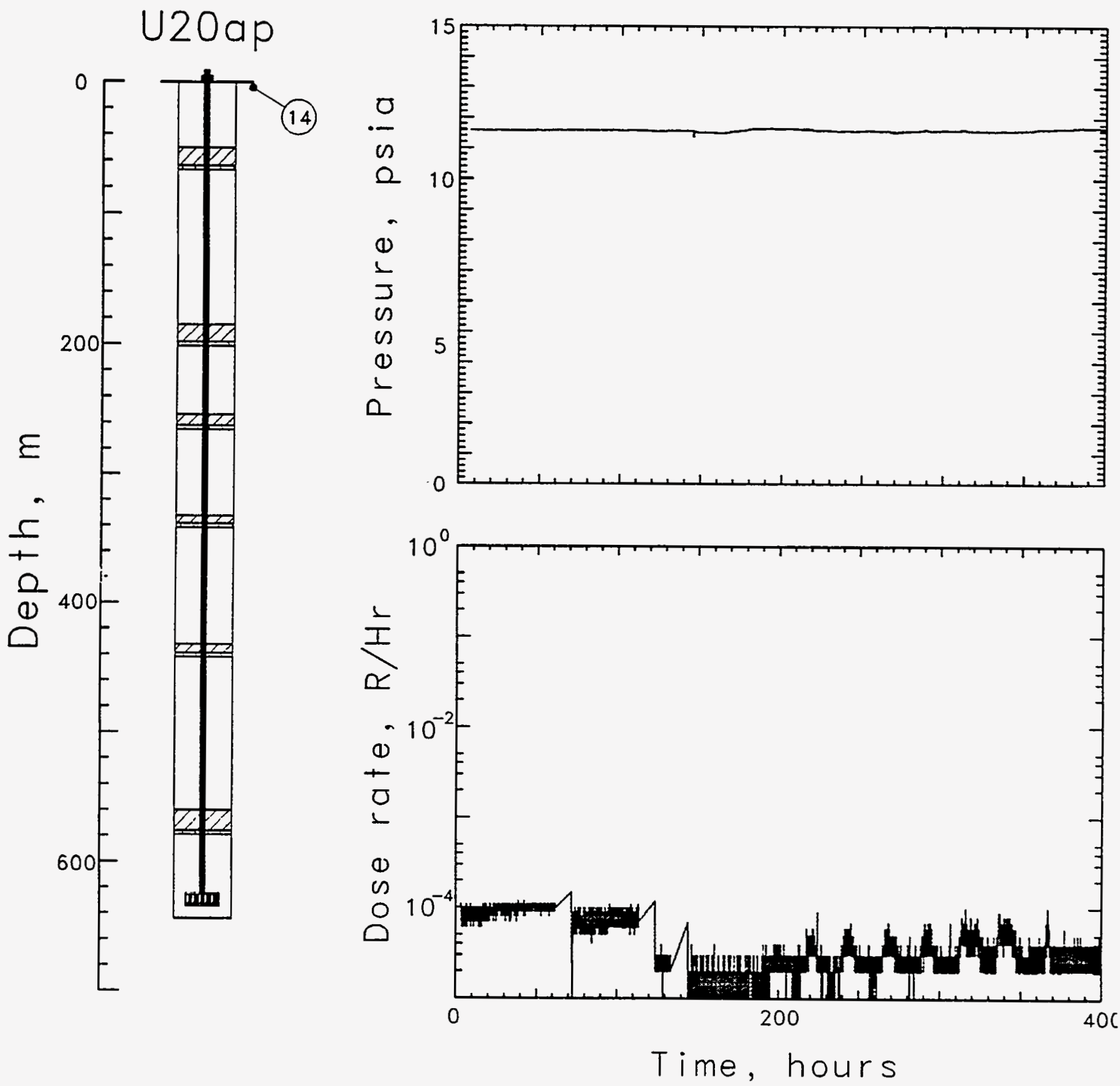

Figure 3.6 Pressure and radiation data from a depth of $0.6 \mathrm{~m}$ and a distance of $15.2 \mathrm{~m}$ from SGZ (Station 14). 

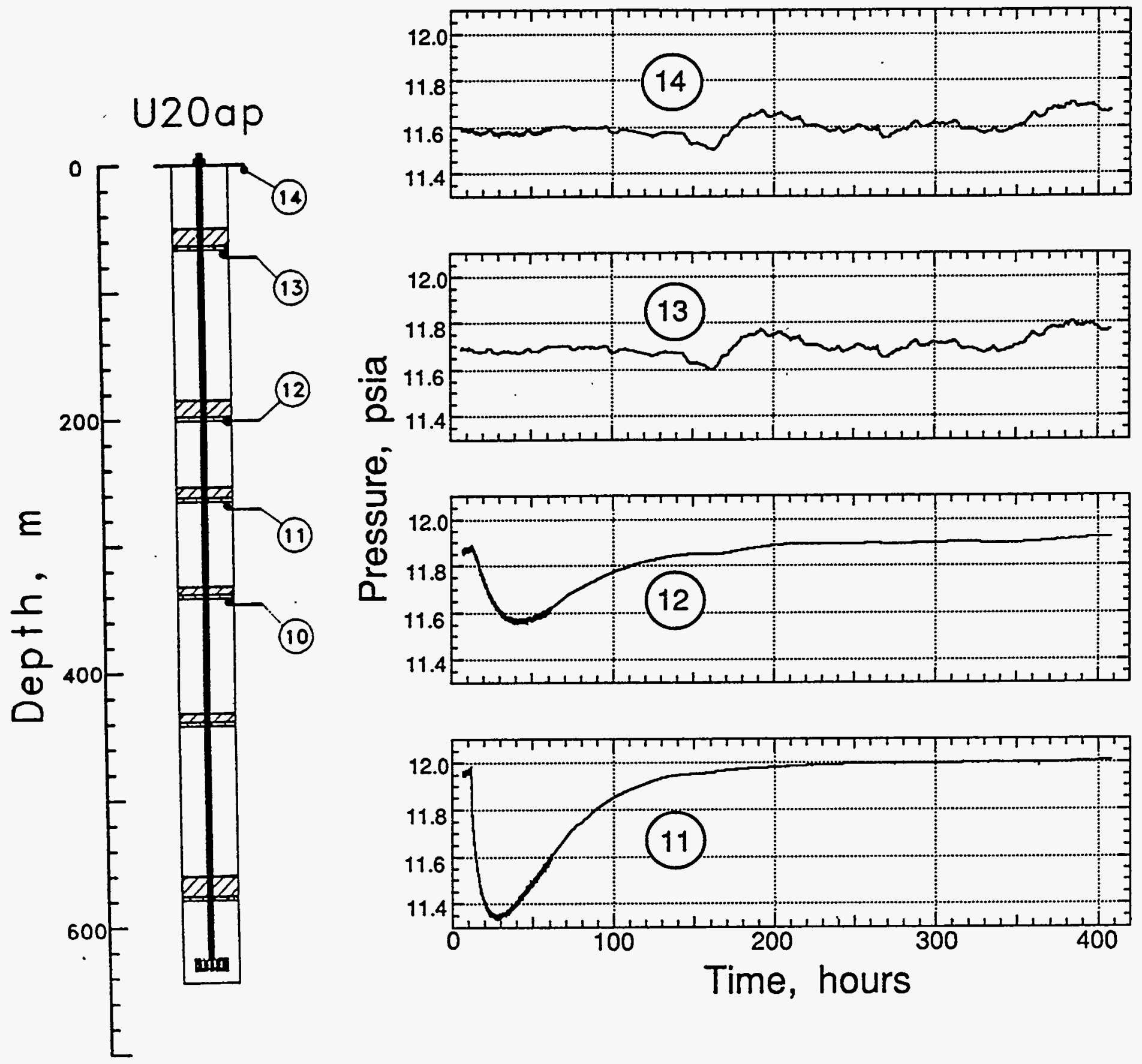

㐫
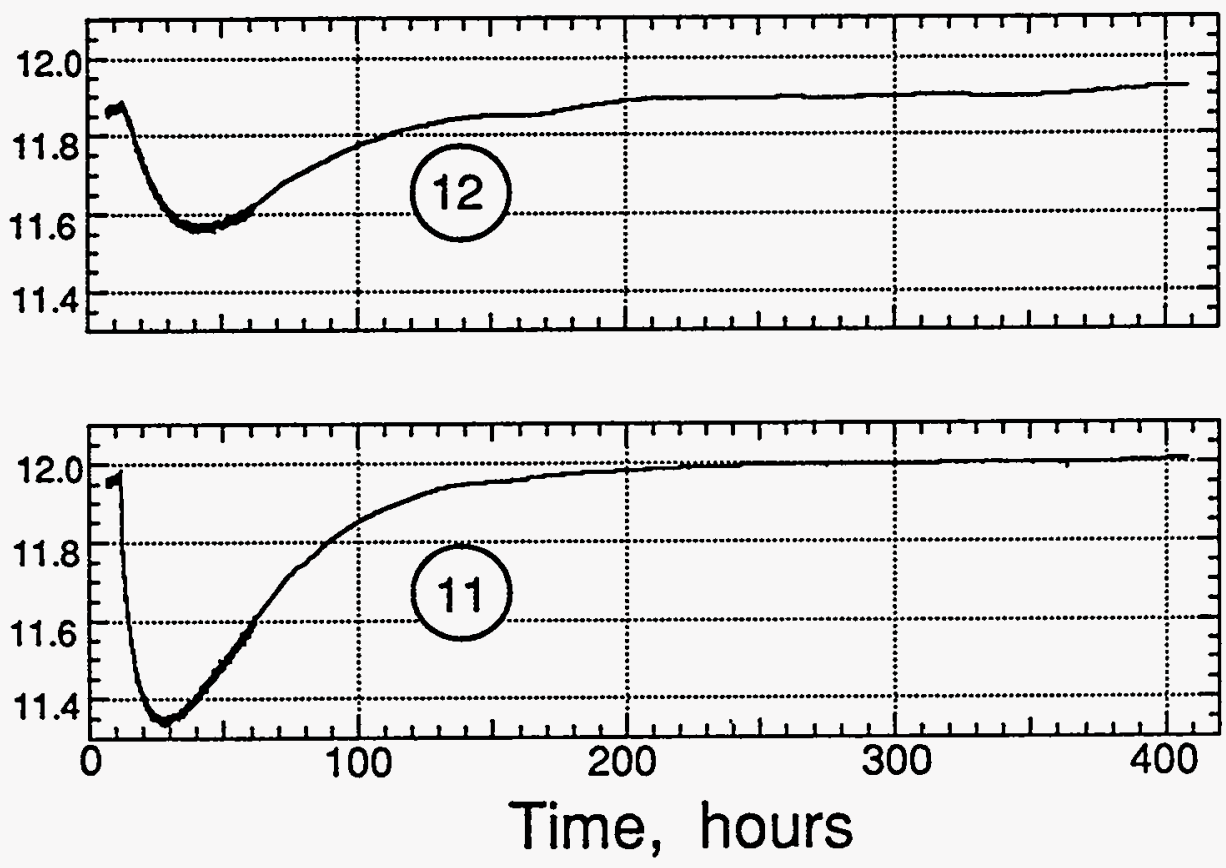

Figure 3.7 Comparison of atmospheric pressure histories measured in the emplacement hole (Stations 11, 12, and 13) compared with the data from Station 14 (in the ground surface). See Figure 3.9 for a composite plot of all of the pressure histories obtained from the emplacement hole. 


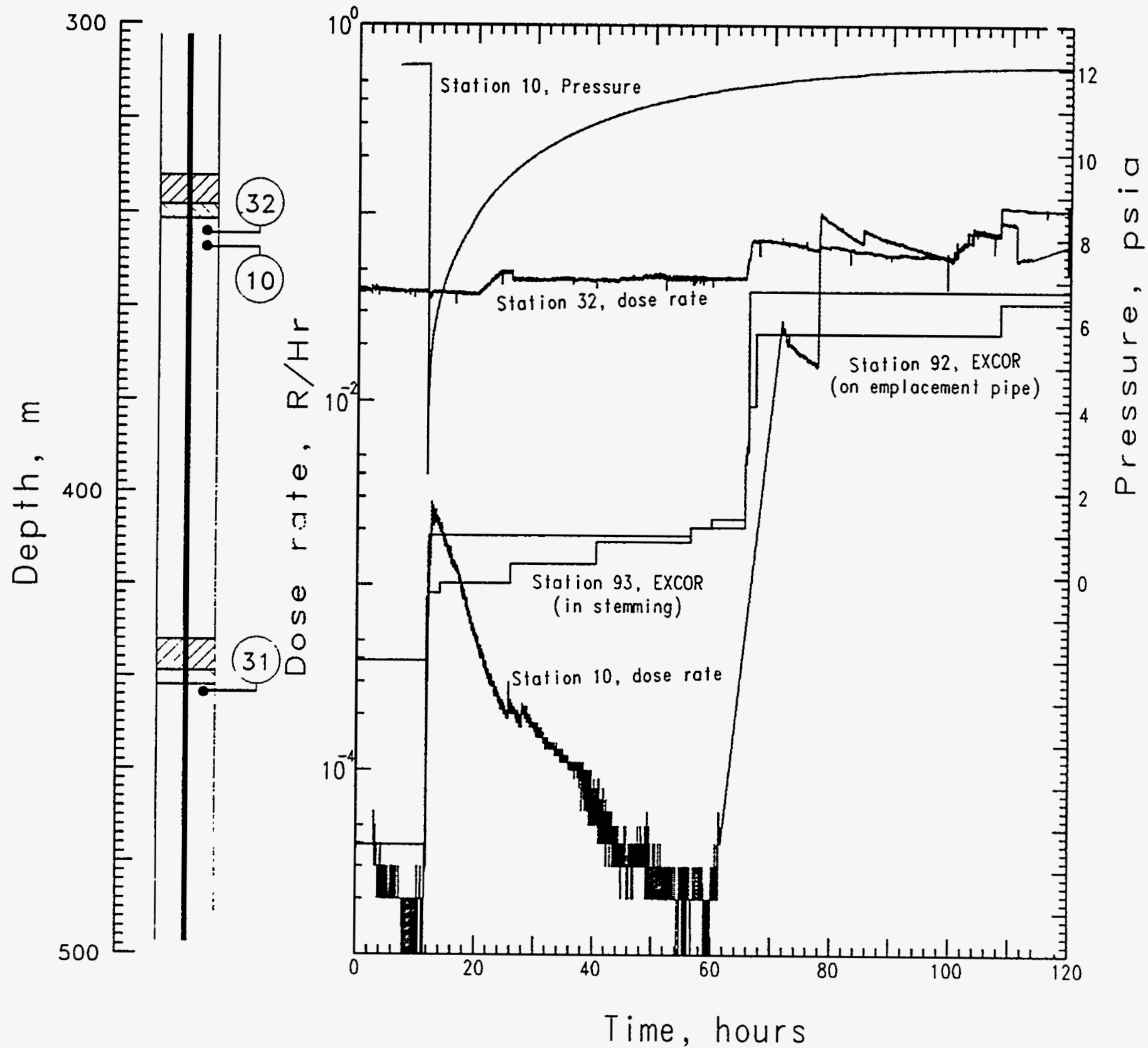

Figure 3.8 Pressure and radiation wave forms measured below Plug 3 compared with EXCOR cable break position. Note the radiation arrivals at about +12 and +66 hours with associated cable breaks but with a visible pressure jump at only the +12 hour event. 


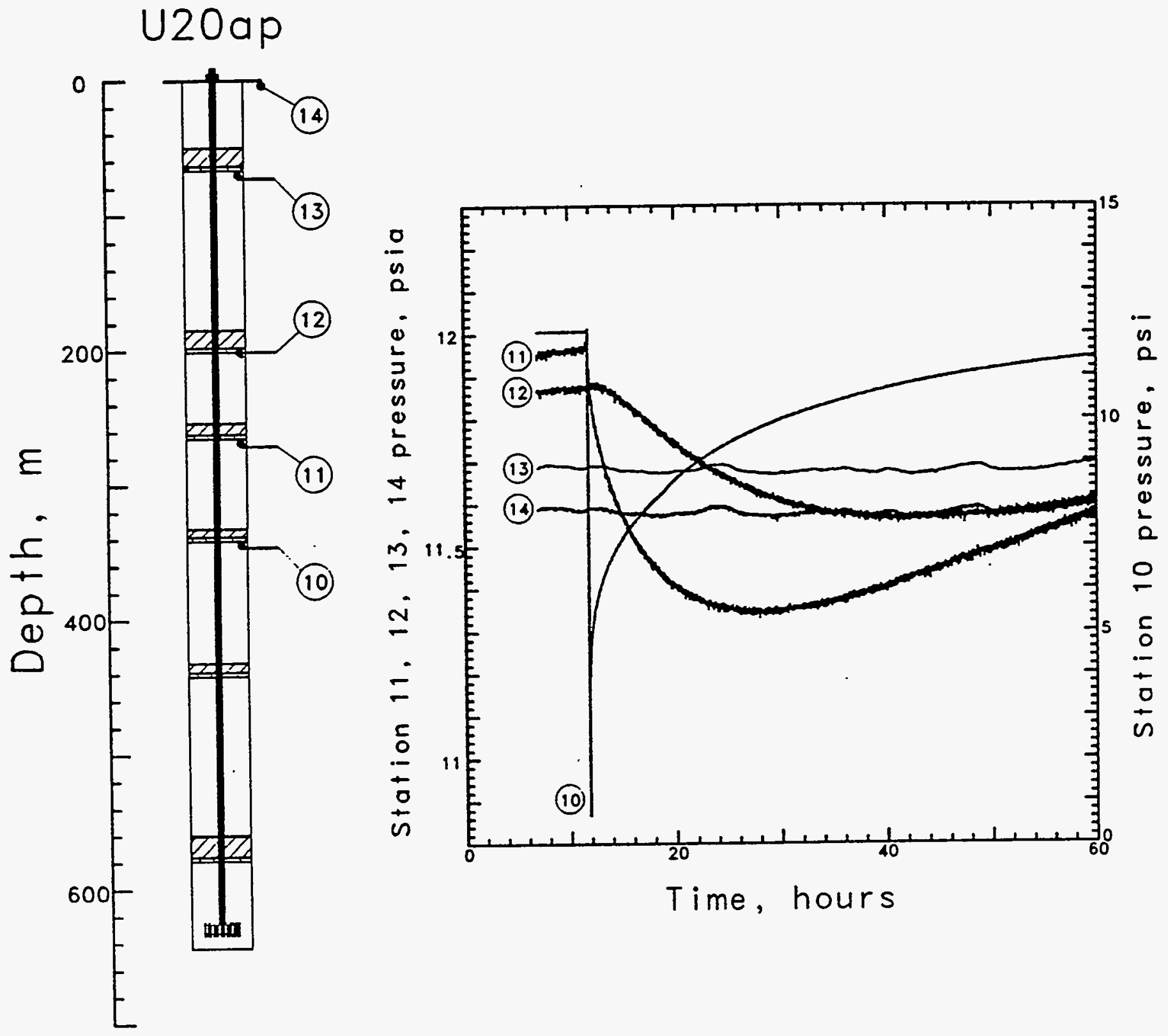

Figure 3.9 A composite of the pressure wave forms measured in the emplacement hole. Note that Station 10 pressure is plotted to a different scale than the other three. 

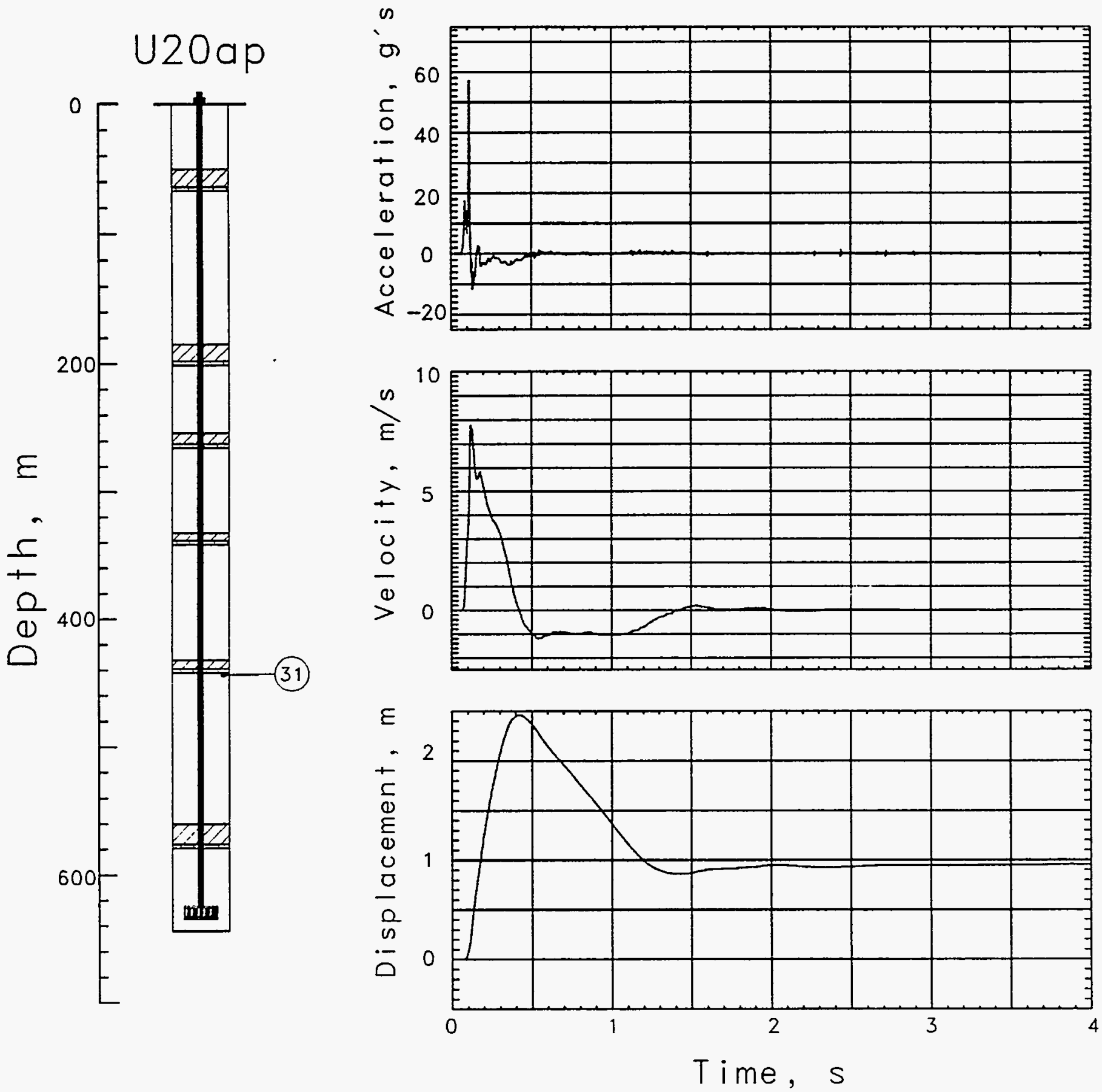

Figure 3.10 Explosion-induced motion of stemming at a depth of $443.5 \mathrm{~m}$ (Station 31). 

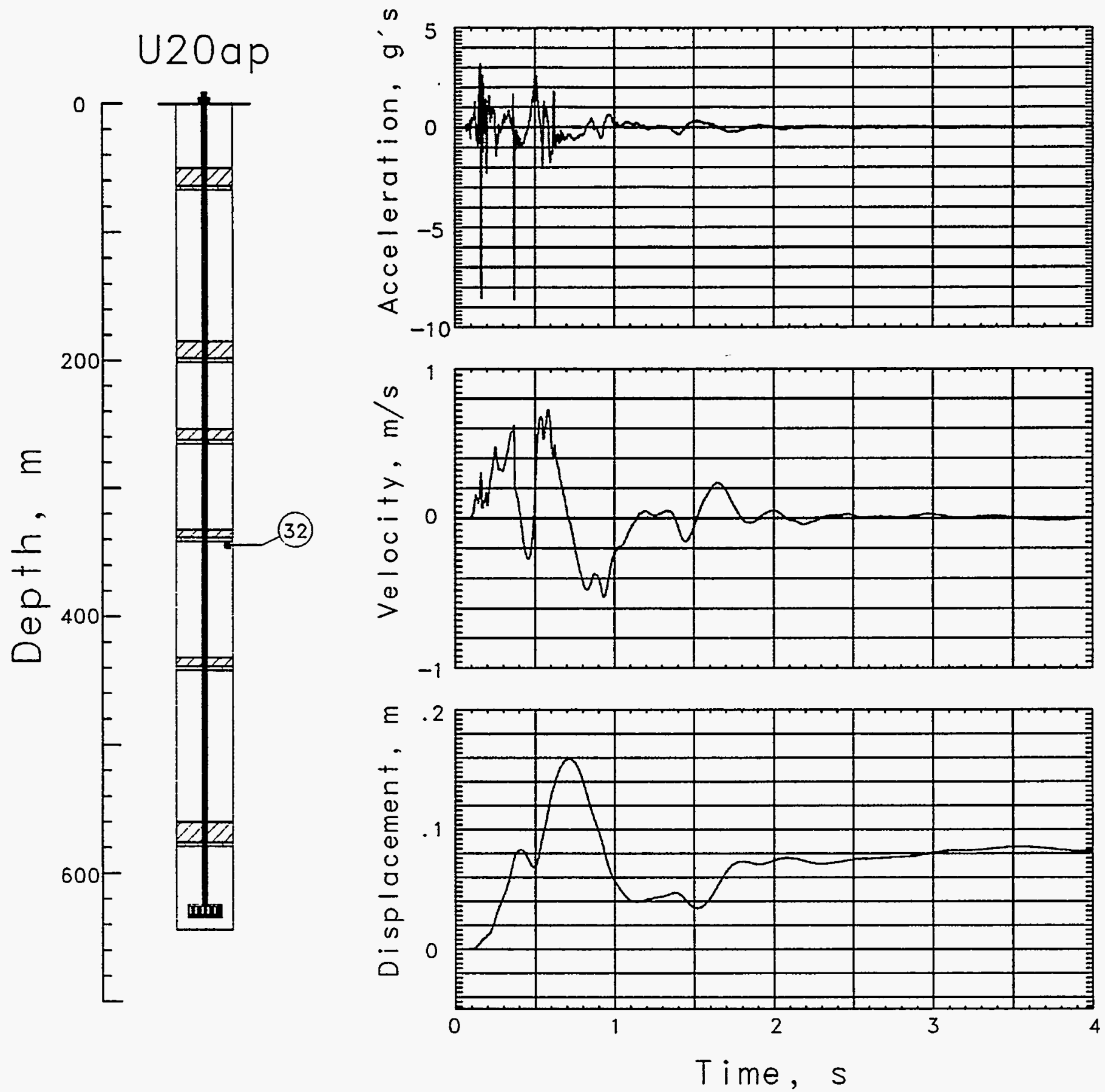

Figure 3.11 Explosion-induced motion of stemming at a depth of $344.4 \mathrm{~m}$ (Station 32). These data are from a transducer installed in a non-vertical orientation and thus yield invalid wave forms and peaks: only the timing should be used. 

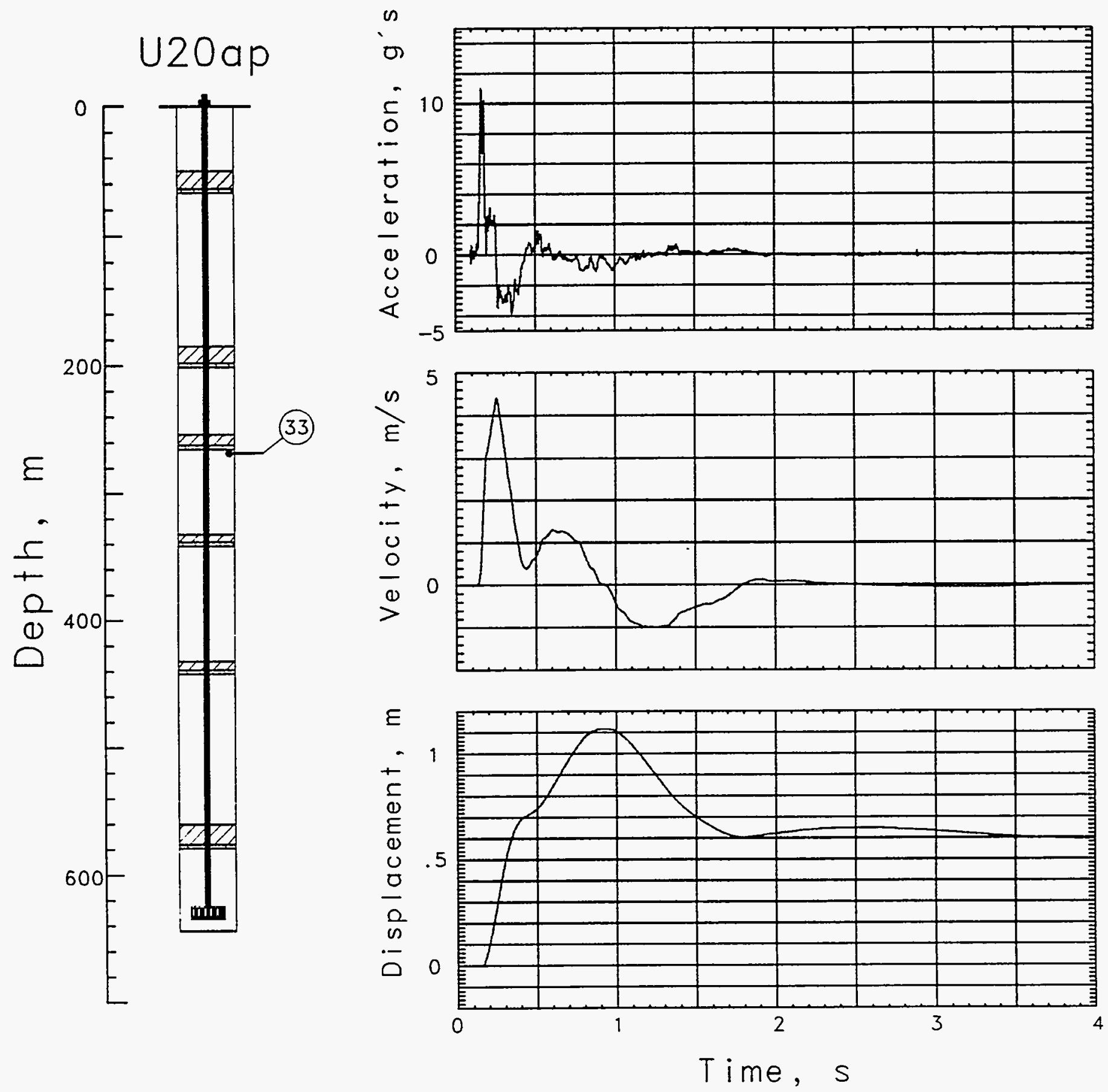

Figure 3.12 Explosion-induced motion of stemming at a depth of $268.2 \mathrm{~m}$ (Station 33). 

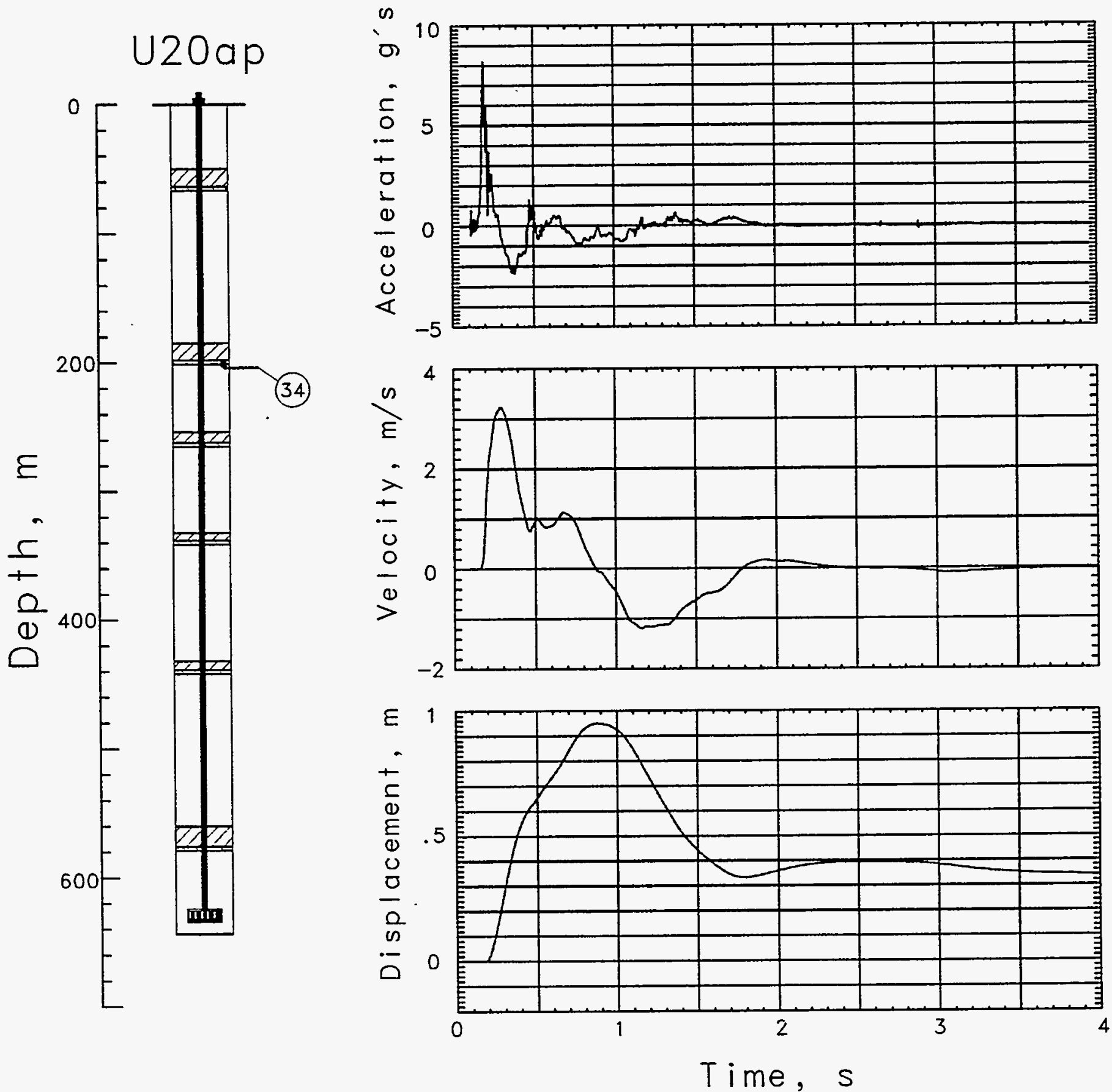

Figure 3.13 Explosion-induced motion of stemming at a depth of $204.2 \mathrm{~m}$ (Station 34). 


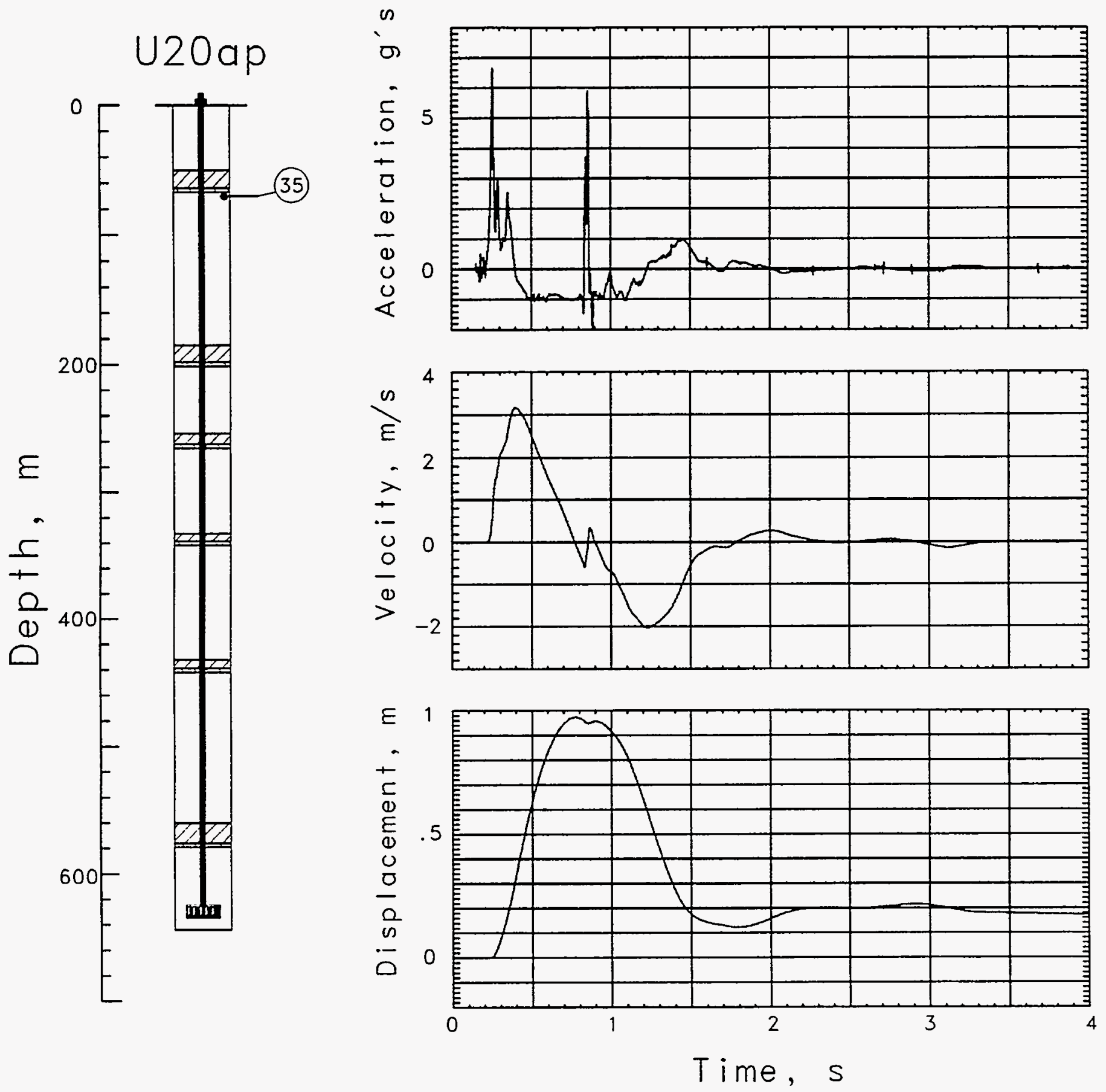

Figure 3.14 Explosion-induced motion of stemming at a depth of $70.1 \mathrm{~m}$ (Station 35). 

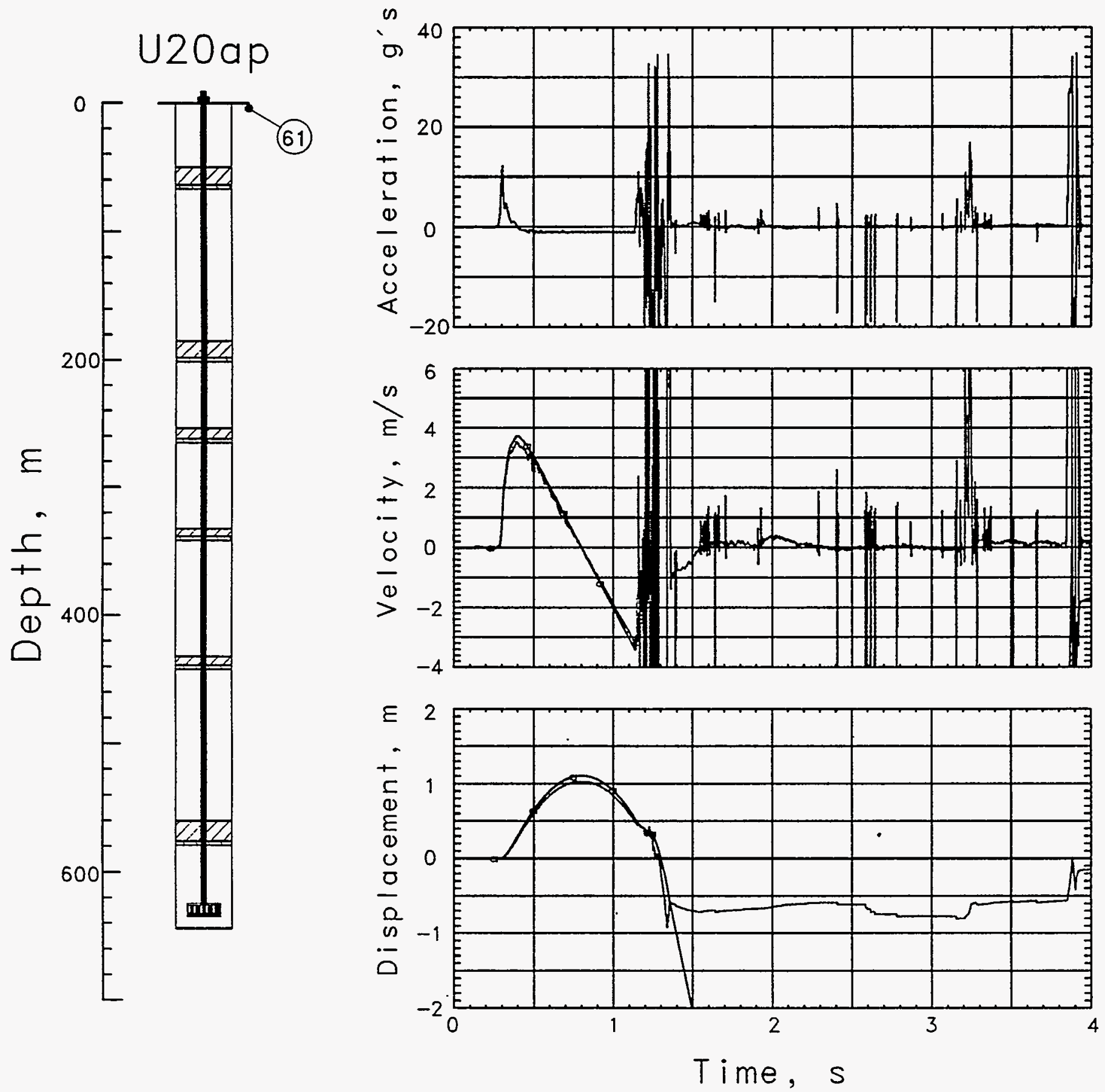

Figure 3.15 Explosion-induced motion of stemming at a depth of $0.6 \mathrm{~m}$ and a horizontal range of $15.2 \mathrm{~m}$ (Station 61). Traces annotated with "a" were derived from the associated accelerometer. 

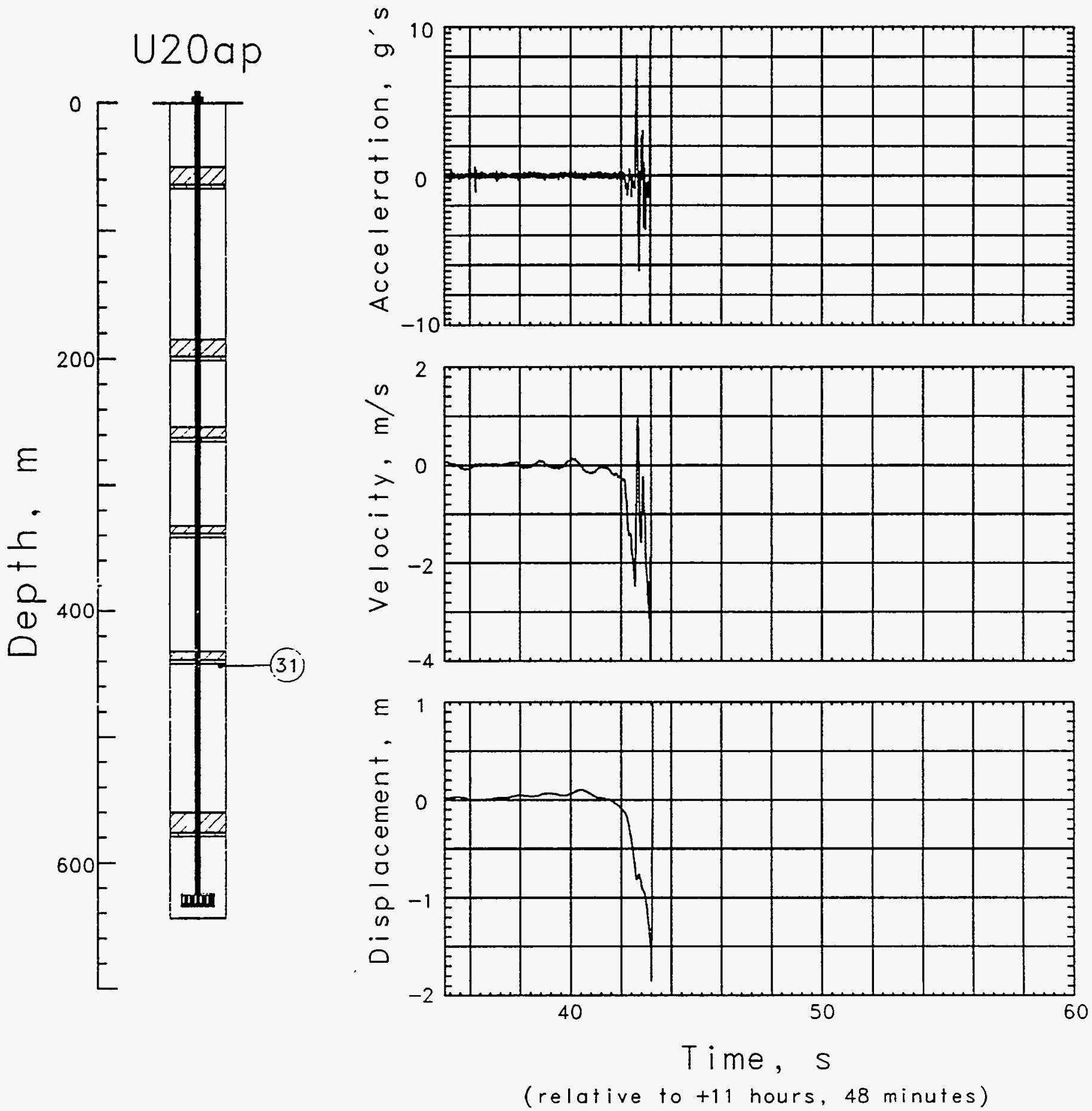

Figure 3.16 Collapse-induced motion of stemming at a depth of $443.5 \mathrm{~m}$ (Station 31). This station was lost at $+11: 48: 43$. 


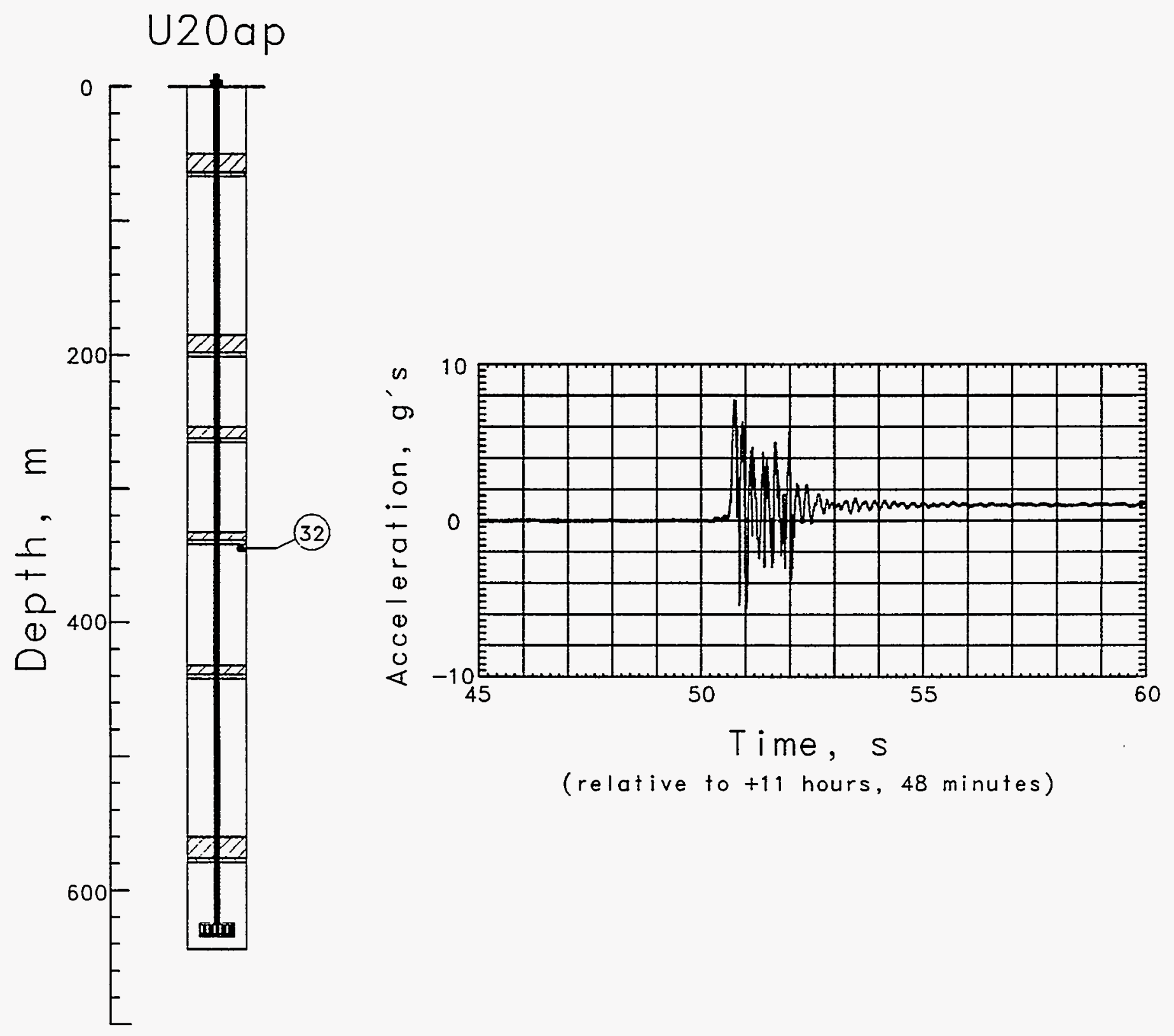

Figure 3.17 Collapse-induced motion of stemming at a depth of $344.4 \mathrm{~m}$ (Station 32). This station was not installed vertically. The low frequency, damped oscillations following the initial motion suggest that the canister was suspended in the absence of stemming. 

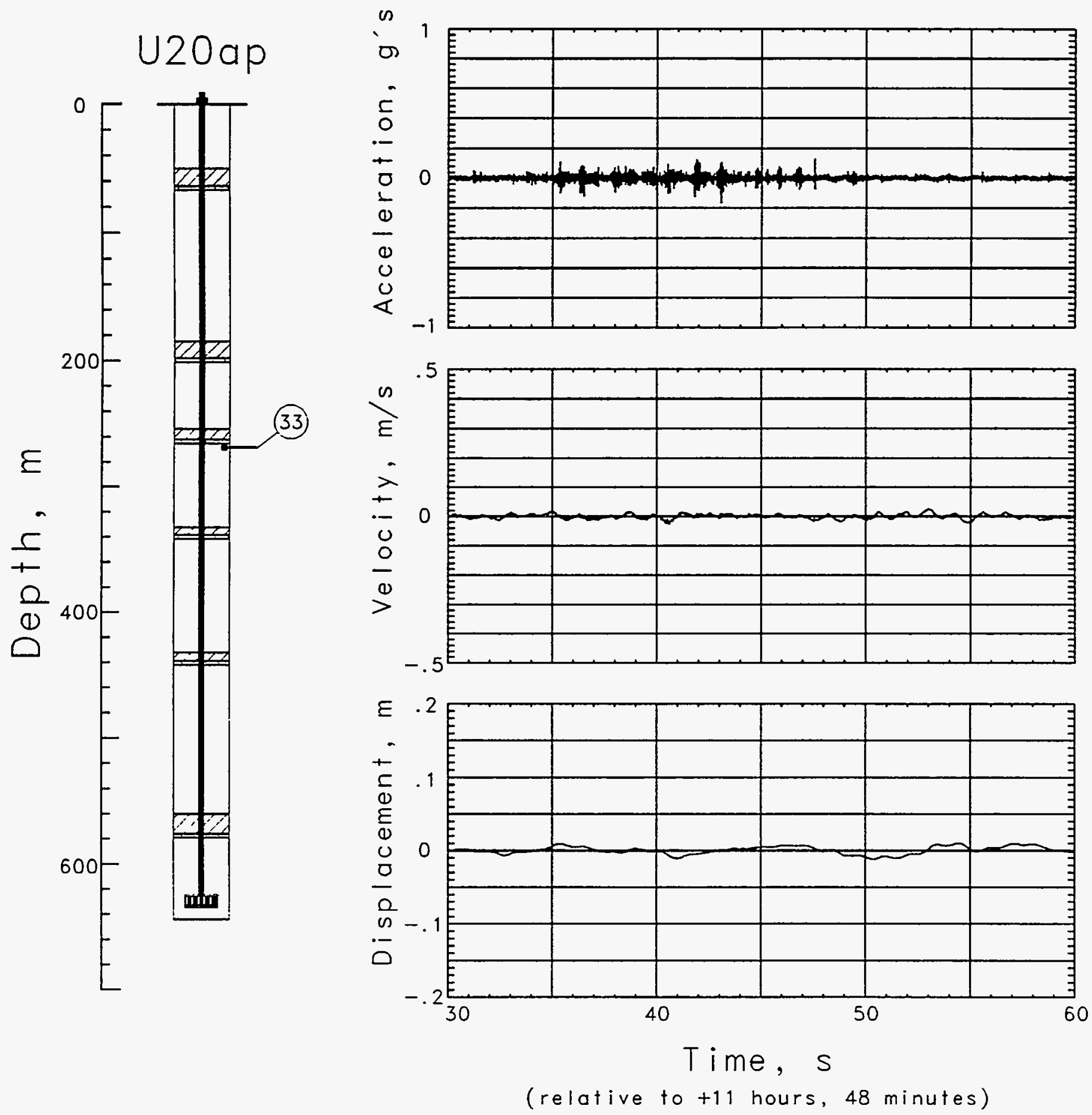

Figure 3.18 Collapse-induced motion of stemming at a depth of $268.2 \mathrm{~m}$ (Station 33). These data are included for completeness. 

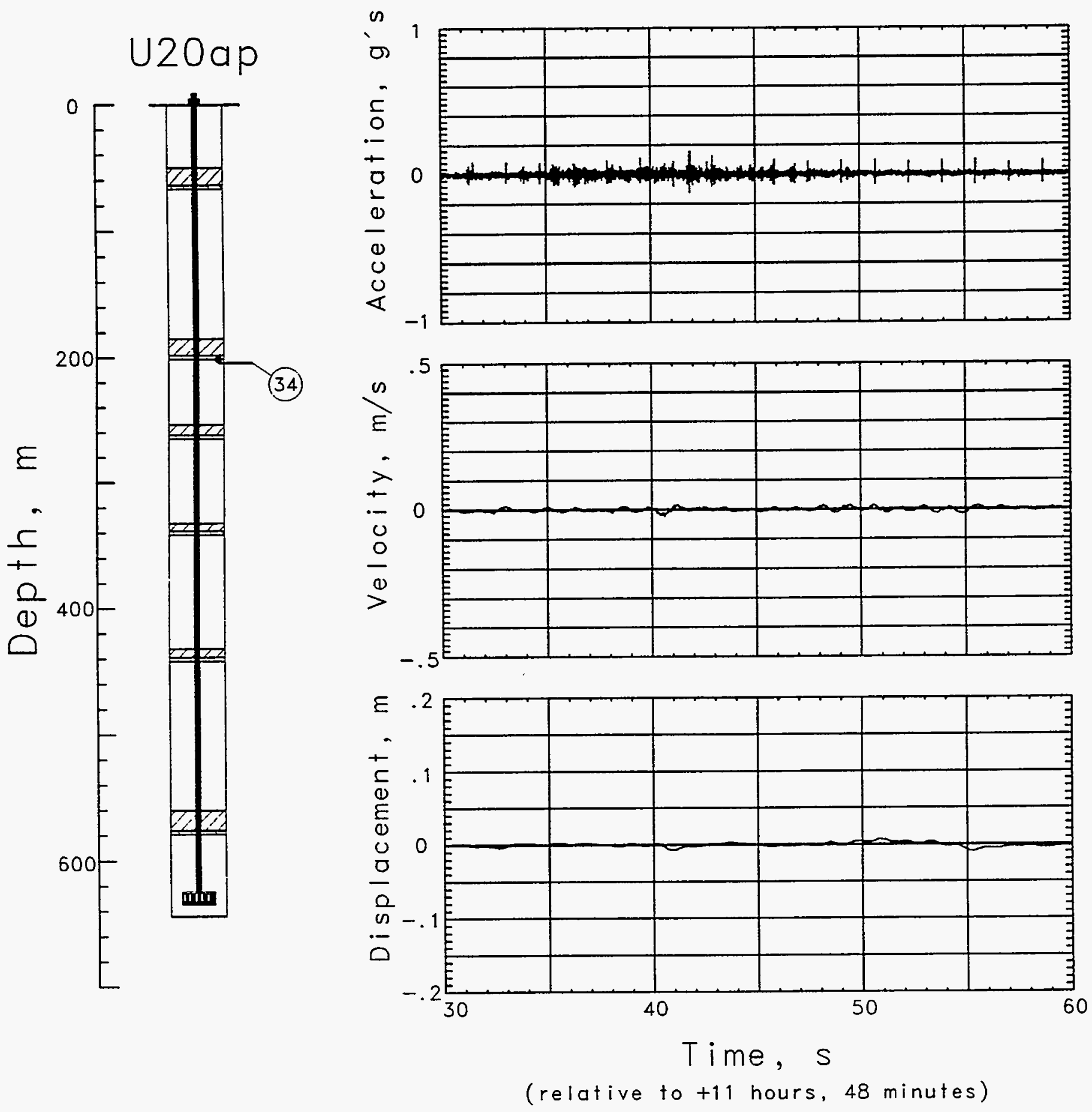

Figure 3.19 Collapse-induced motion of stemming at a depth of $204.2 \mathrm{~m}$ (Station 34). These data are included for completeness. 

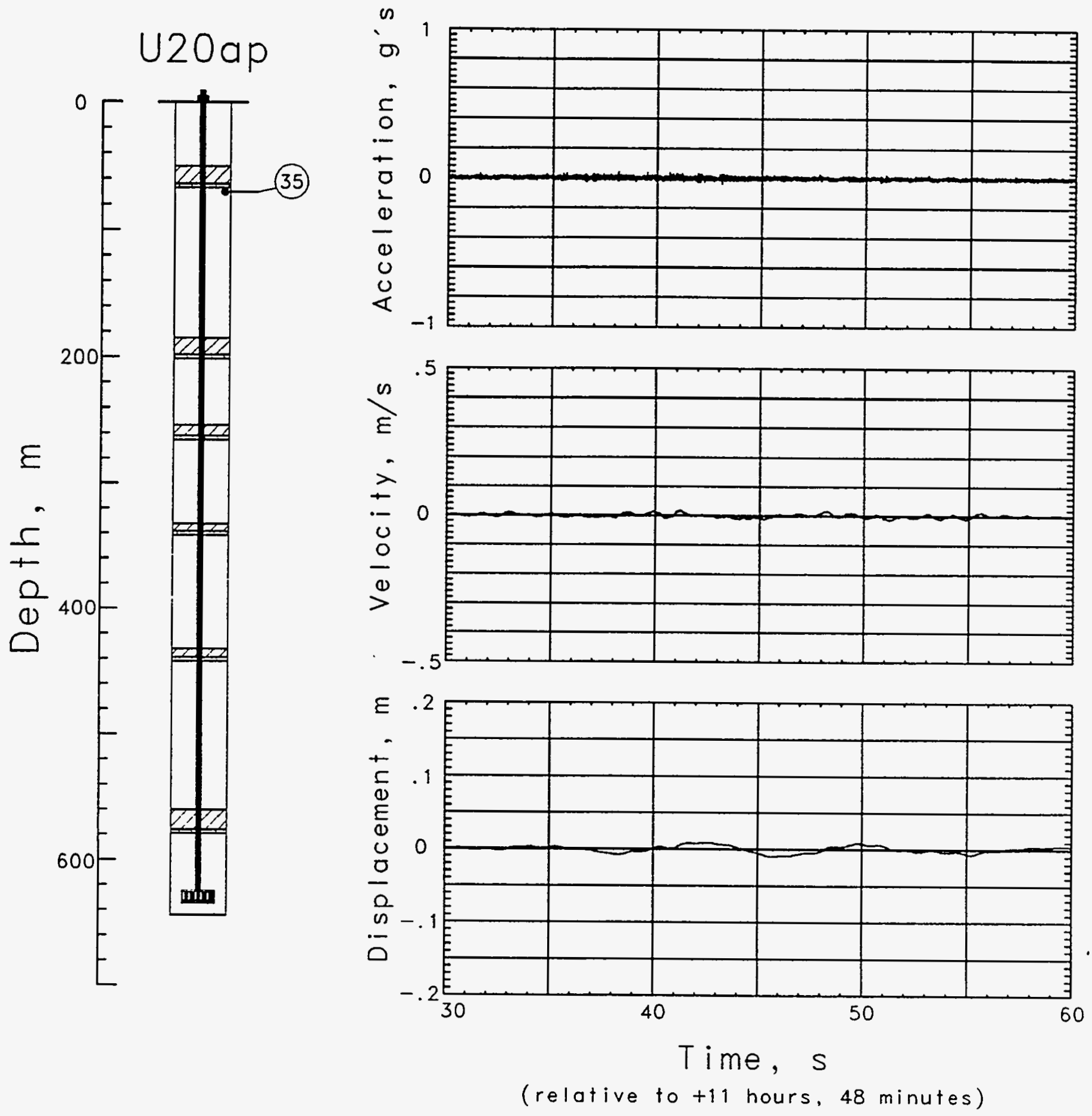

Figure 3.20 Collapse-induced motion of stemming at a depth of $70.1 \mathrm{~m}$ (Station 35). These data are included for completeness. 


\section{Table 3.1 Summary of Motion}

\begin{tabular}{|c|c|c|c|c|c|c|}
\hline Gauge & $\begin{array}{c}\text { Slant Range } \\
\text { (m) }\end{array}$ & $\begin{array}{l}\text { Arrival Time } \\
\text { (ms) }\end{array}$ & $\begin{array}{c}\text { Acceleration } \\
\text { Peak (g's) }\end{array}$ & $\begin{array}{l}\text { Velocity Peak } \\
(\mathrm{m} / \mathrm{s})\end{array}$ & $\begin{array}{l}\text { Displacement } \\
\text { Peak (m) }\end{array}$ & $\begin{array}{l}\text { Displacement } \\
\text { Residual (m) }\end{array}$ \\
\hline $31 a v$ & 190.5 & 62,97 & 115 & 15.5 & 2.5 & 0.92 \\
\hline $32 a v$ & 289.6 & 69,115 & - & (a) & - & - \\
\hline $33 a v$ & 365.8 & 92,139 & 11.0 & 4.4 & 1.1 & 0.60 \\
\hline $34 a v$ & 429.8 & 108,162 & 8.2 & 3.25 & 0.95 & 0.34 \\
\hline $35 a v$ & 563.9 & 149,220 & 6.7 & 3.20 & 0.97 & 0.17 \\
\hline $61 a v$ & 634 & 263 & 12.2 & 3.75 & 1.10 & (b) \\
\hline 61uv & - & - & - & 3.49 & 1.03 & (b) \\
\hline
\end{tabular}

(a) This station was improperly oriented; only the timing data are valid.

(b) Noise precludes determination of this value. 
Iable 3.2 Accelerometer Characteristics

\begin{tabular}{lcccc} 
Gauge & $\begin{array}{c}\text { Natural Frequency } \\
(\mathrm{Hz})\end{array}$ & Damping Ratio & $\begin{array}{c}\text { System Range } \\
(\mathrm{g} \text { 's) }\end{array}$ \\
\cline { 5 - 5 } 31av & 5350 & na & 250 \\
32av & 2490 & na & 62.5 \\
33av & 2420 & na & 25.0 \\
34av & 2550 & na & 25.0 \\
35av & 2350 & na & 25.0 \\
61av & 619 & 0.65 & 50.0
\end{tabular}

Iable 3,3 Velocimeter Characteristics

\begin{tabular}{|c|c|c|c|c|c|}
\hline Gauge & $\begin{array}{l}\text { Natural } \\
\text { Frequency } \\
(\mathrm{Hz})\end{array}$ & $\begin{array}{c}\text { Time to } 0.5 \\
\text { Amplitude } \\
\text { (s) }\end{array}$ & $\begin{array}{c}\text { Calibration } \\
\text { Temperature } \\
\left({ }^{\circ} \mathrm{C}\right)\end{array}$ & $\begin{array}{c}\text { Operate } \\
\text { Temperature } \\
\left({ }^{\circ} \mathrm{C}\right)\end{array}$ & $\begin{array}{c}\text { System } \\
\text { Range } \\
(\mathrm{m} / \mathrm{s})\end{array}$ \\
\hline 61uv & 3.438 & 10.74 & 25.26 & 2.91 & 12 \\
\hline
\end{tabular}




\section{Other Measurements}

4.1 Behavior of the Recording trailer

The measured and derived explosion-induced motions from the transducers fielded in the recording trailer are summarized in Table 4.1. Tables 4.2 and 4.3 give the transducer characteristics of these gauges.

A major disruption of the recorded signals for the data taken in the high-level end of Trailer 983 occurred between 1.2 and 1.4 seconds (at the time of slap-down) with many subsequent noise spikes, invalidating the integrals of the motion at later times. Figures 4.1 4.3 show the measured and derived trailer motion wave forms. The displacement trajectories of the trailer in both the horizontal plane and the vertical plane (including the emplacement hole and the horizontal radius vector from it) are shown in Figure 4.4. 

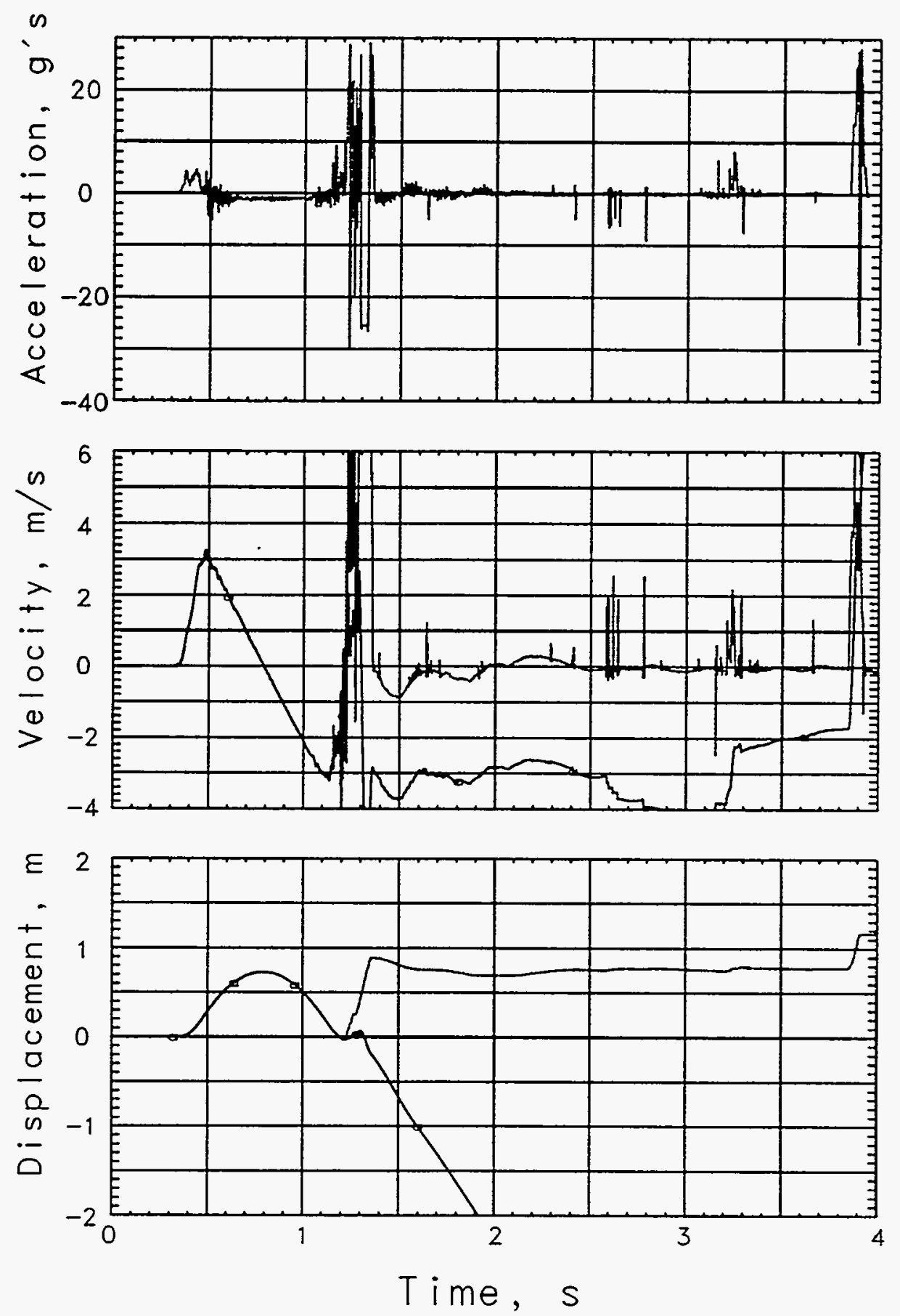

Figure 4.1 Explosion-induced vertical motion of recording trailer 983. Traces annotated with "a" were derived from the associated accelerometer. 

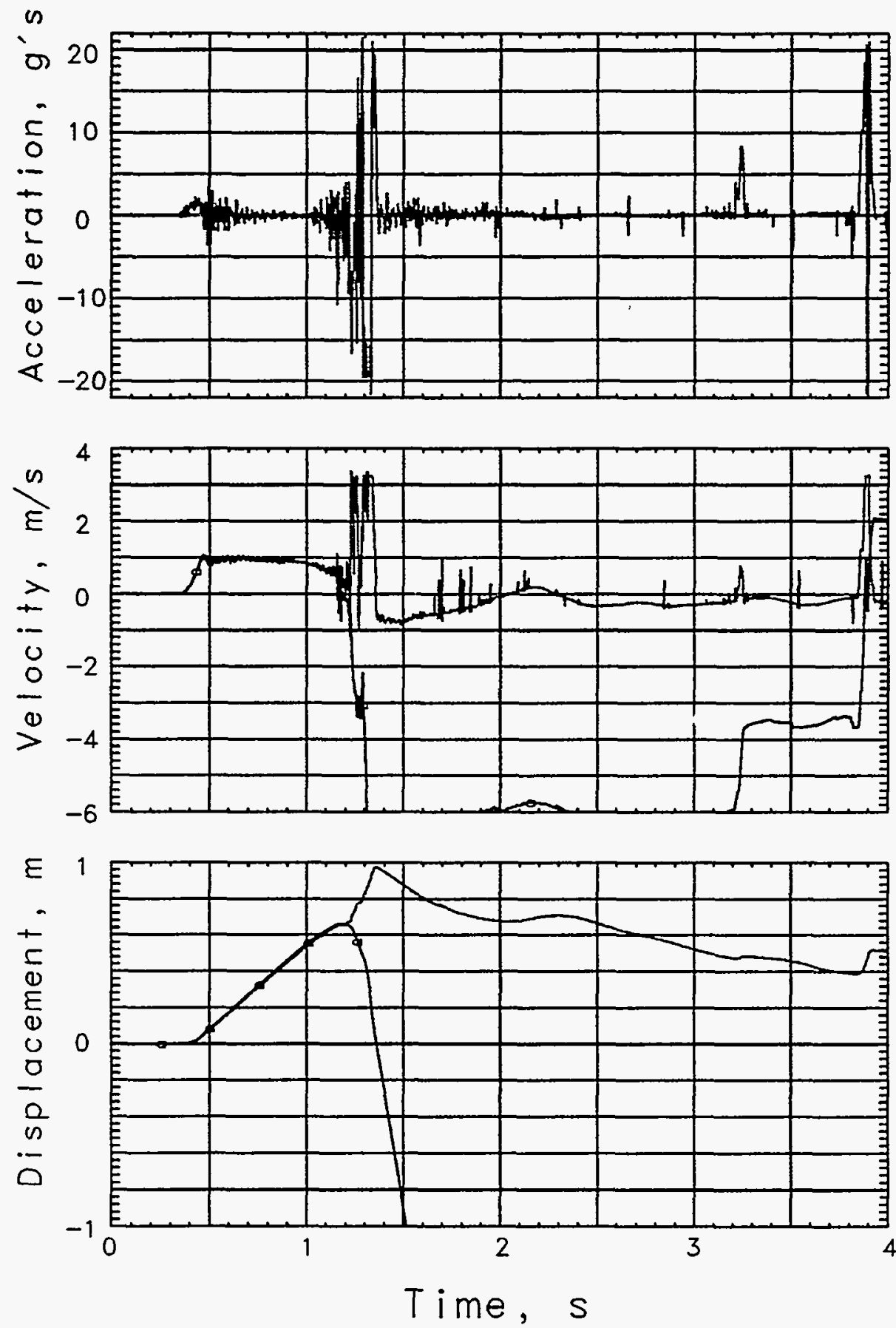

Figure 4.2 Explosion-induced horizontal-radial motion of recording trailer 983 . Traces annotated with "a" were derived from the associated accelerometer. 

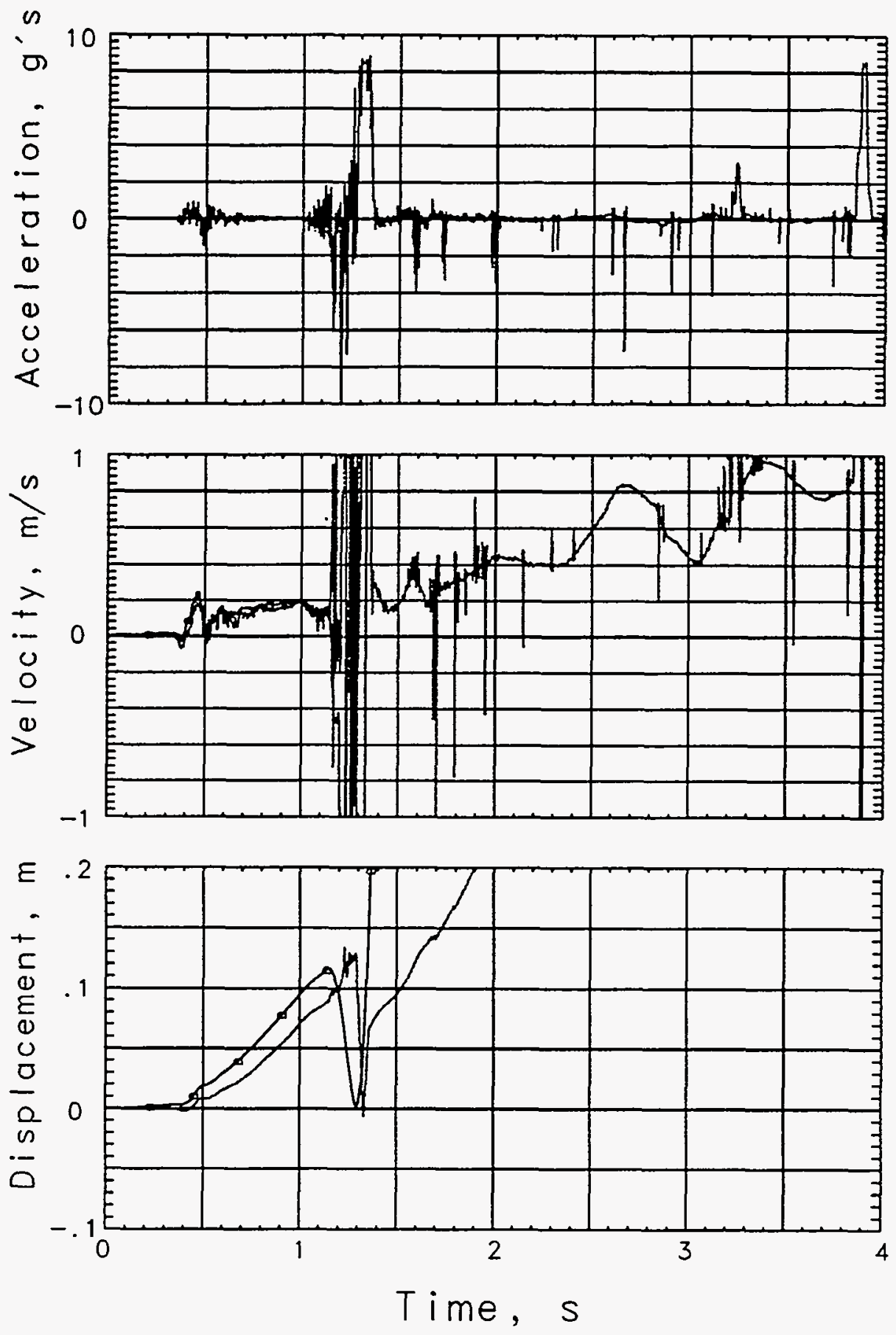

Figure 4.3 Explosion-induced horizontal-transverse motion of recording trailer 983. Traces annotated with "a" were derived from the associated accelerometer. 

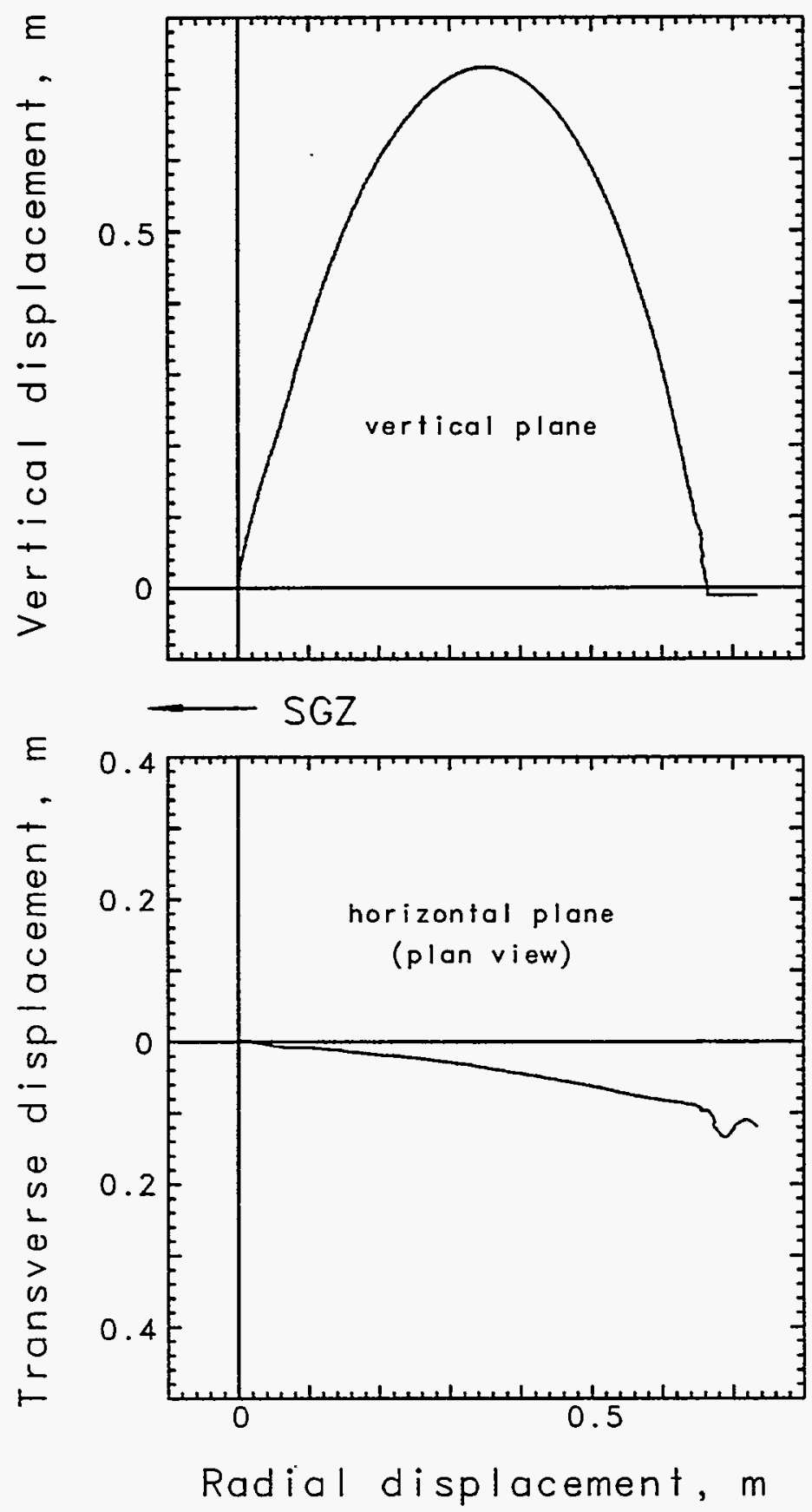

Figure 4.4 Displacement trajectories of the recording trailer. 
Table 4.2 Summary of Motion

\begin{tabular}{|c|c|c|c|c|c|c|}
\hline Gauge & $\begin{array}{l}\text { Slant Range } \\
(m)(a)\end{array}$ & $\begin{array}{l}\text { Arrival Time } \\
\text { (ms) }\end{array}$ & $\begin{array}{c}\text { Acceleration } \\
\text { Peak (g) }\end{array}$ & $\begin{array}{l}\text { Velocity Peak } \\
(\mathrm{m} / \mathrm{s})\end{array}$ & $\begin{array}{l}\text { Displacement } \\
\text { Peak (m) }\end{array}$ & $\begin{array}{l}\text { Displacement } \\
\text { Residual }(\mathrm{m})\end{array}$ \\
\hline $71 a v$ & $707(a)$ & 320 & 4.7 & 3.30 & 0.73 & (b) \\
\hline $71 u v$ & - & - & - & 3.30 & 0.73 & (b) \\
\hline $71 \mathrm{ar}$ & $707(a)$ & 330 & 3.5 & 1.05 & 0.66 & (b) \\
\hline $71 u r$ & - & - & - & 1.05 & 0.66 & (b) \\
\hline 71at & $707(a)$ & 320 & 1.0 & 0.21 & 0.116 & (b) \\
\hline 71ut & - & - & - & 0.18 & 0.097 & (b) \\
\hline
\end{tabular}

(a) Station in recording trailer about .5 DoB from SGZ.

(b) Noise precludes determination of this value.

Table 4.3 Accelerometer Characteristics

\begin{tabular}{|c|c|c|c|}
\hline Gauge & $\begin{array}{c}\text { Natural Frequency } \\
(\mathrm{Hz})\end{array}$ & Damping Ratio & $\begin{array}{c}\text { System Range } \\
\text { (g's) }\end{array}$ \\
\hline $71 a v$ & 350 & 0.65 & 20 \\
\hline $71 a r$ & 420 & 0.85 & 15 \\
\hline 71at & 300 & 0.55 & 15 \\
\hline
\end{tabular}

Table 4.4 Velocimeter Characteristics

\begin{tabular}{|c|c|c|c|c|c|}
\hline Gauge & $\begin{array}{c}\text { Natural } \\
\text { Frequency } \\
(\mathrm{Hz})\end{array}$ & $\begin{array}{l}\text { Time to } 0.5 \\
\text { Amplitude } \\
\text { (s) }\end{array}$ & $\begin{array}{c}\text { Calibration } \\
\text { Temperature } \\
\left({ }^{\circ} \mathrm{C}\right)\end{array}$ & $\begin{array}{c}\text { Operate } \\
\text { Temperature } \\
\left({ }^{\circ} \mathrm{C}\right)\end{array}$ & $\begin{array}{c}\text { System } \\
\text { Range } \\
(\mathrm{m} / \mathrm{s})\end{array}$ \\
\hline 71uv & 3.515 & 9.28 & 25.75 & 12.70 & 7.0 \\
\hline 71ur & 3.334 & 9.40 & 24.95 & 12.70 & 5.0 \\
\hline 71ut & 3.315 & 9.29 & 25.01 & 12.70 & 5.0 \\
\hline
\end{tabular}




\section{References}

1. K. E. Raschke, "Radioactive Seep at BODIE - U20ap", KER-22-87, Nuclear Test

Operations, Lawrence Livermore National Laboratory, Livermore, CA, September 23, 1987.

2. Stephen Clark and Casey Schmidt, "U20ap Site Characteristics Report," CP 86-48, Lawrence Livermore National Laboratory, Livermore, CA, September 12, 1986.

3. Alfred E. Burer, "Containment Report for U20ap," Holmes \& Narver, NTS:A2:86-97, December 10, 1986.

4. W. G. Webb, “Special Measurements Final Engineering Report, BODIE, U20ap" EG\&G, Energy Measurements, Las Vegas, NV, SM:86E-140-23, 30, January, 1987.

5. W. G. Webb, "Special Measurements Physics/Instrumentation BODIE, U20ap" EG\&G, Energy Measurements, Las Vegas Operations, SM:86E-140-15, 29 October, 1986.

6. LLNL contact for additional information: $R$. Heinle 